
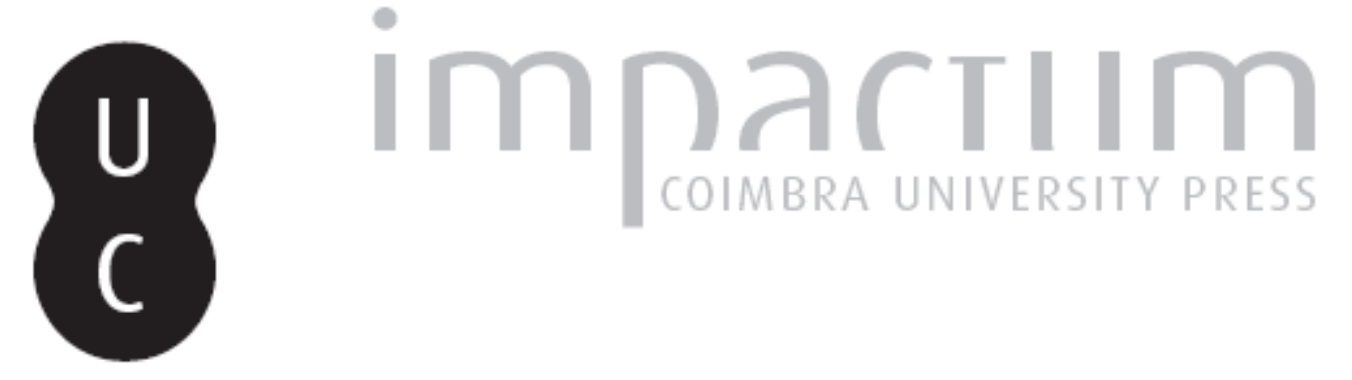

Ovos, ovos, ovos e mais ovos: cultura, economia, dietética e gastronomia

Autor(es): $\quad$ Braga, Isabel M. R. Mendes Drumond

Publicado por: Centro de História da Sociedade e da Cultura

URL persistente:

URI:http://hdl.handle.net/10316.2/39400

DOI:

DOI:http://dx.doi.org/10.14195/1645-2259_13_18

Accessed : $\quad$ 26-Apr-2023 16:22:06

A navegação consulta e descarregamento dos títulos inseridos nas Bibliotecas Digitais UC Digitalis, UC Pombalina e UC Impactum, pressupõem a aceitação plena e sem reservas dos Termos e Condições de Uso destas Bibliotecas Digitais, disponíveis em https://digitalis.uc.pt/pt-pt/termos.

Conforme exposto nos referidos Termos e Condições de Uso, o descarregamento de títulos de acesso restrito requer uma licença válida de autorização devendo o utilizador aceder ao(s) documento(s) a partir de um endereço de IP da instituição detentora da supramencionada licença.

Ao utilizador é apenas permitido o descarregamento para uso pessoal, pelo que o emprego do(s) título(s) descarregado(s) para outro fim, designadamente comercial, carece de autorização do respetivo autor ou editor da obra.

Na medida em que todas as obras da UC Digitalis se encontram protegidas pelo Código do Direito de Autor e Direitos Conexos e demais legislação aplicável, toda a cópia, parcial ou total, deste documento, nos casos em que é legalmente admitida, deverá conter ou fazer-se acompanhar por este aviso.

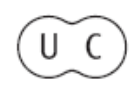



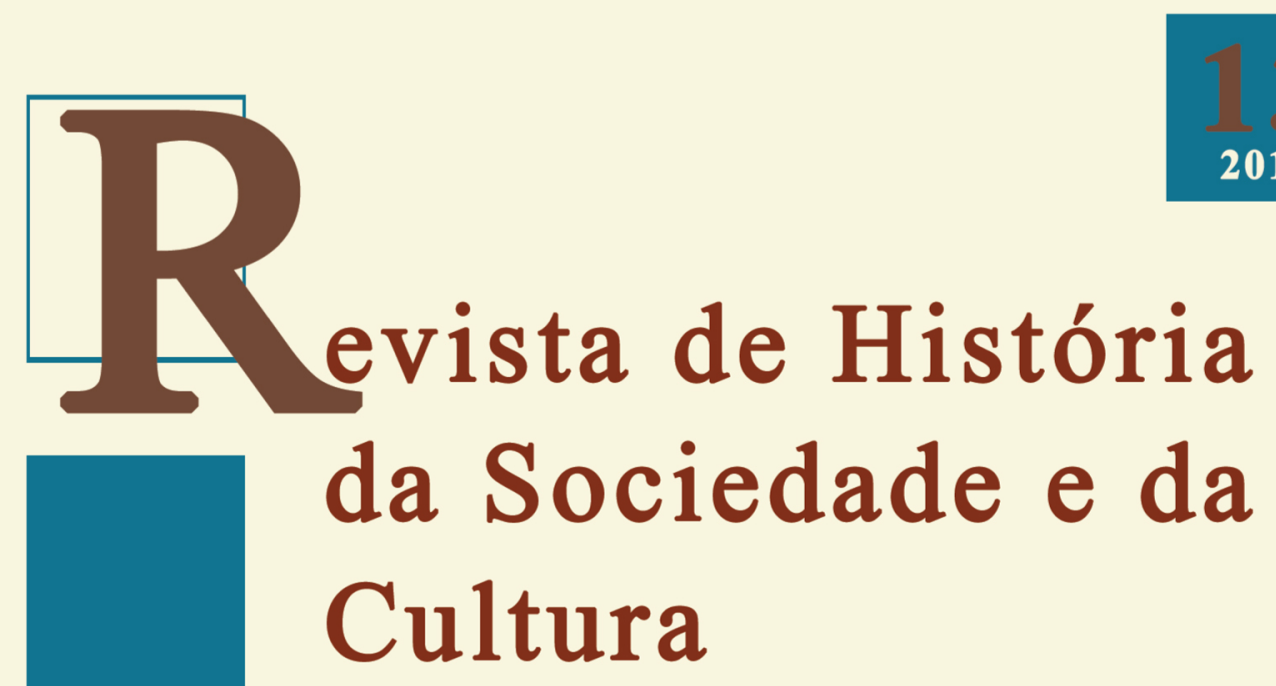

2013

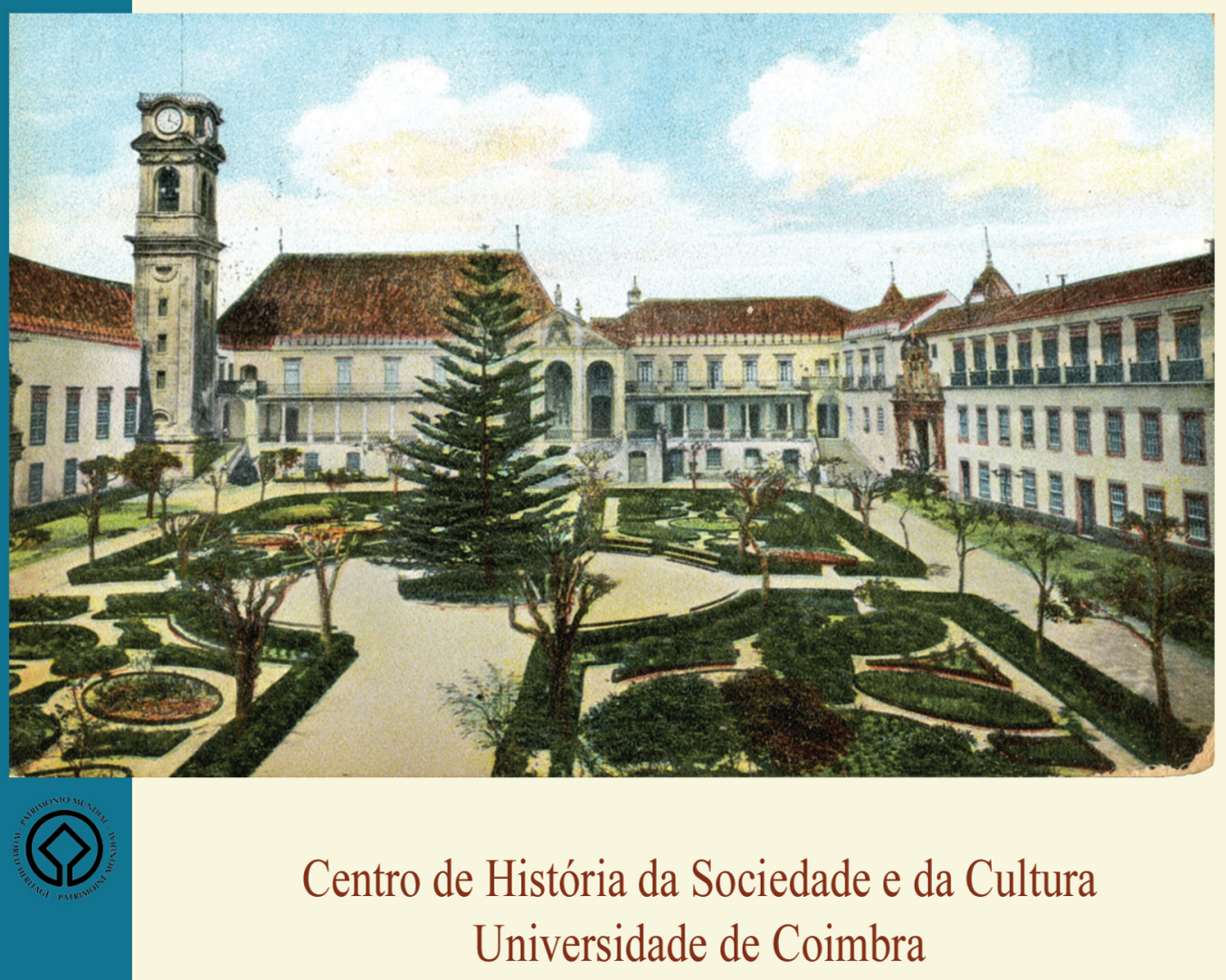

Coimbra 


\title{
Ovos, Ovos, Ovos e mais Ovos \\ Cultura, Economia, Dietética e Gastronomia
}

\author{
Isabel M. R. Mendes Drumond Braga \\ Faculdade de Letras da Universidade de Lisboa \\ isabeldrumondbraga@hotmail.com \\ Texto recebido em /Text submitted on: 06/05/2013 \\ Texto aprovado em /Text approved on: 14/10/2013
}

Resumo/Abstract:

Partindo de fontes diversificadas, nomeadamente iconografia, livros de receitas, obras de medicina, provérbios e contratos agrários, pretendeu analisar-se e explicar-se a relevância dos ovos no quotidiano de outrora. O estudo abrange em especial: valor real e valor simbólico do ovo, o ovo na cultura popular, na medicina, no receituário de beleza e na gastronomia.

Using diverse sources, including iconography, cookbooks, books of medicine, proverbs and land contracts, is intended to analyze and explain the relevance of the eggs in the everyday life of the past. The study covers in particular: real value and symbolic value of the egg, the egg in popular culture, medicine, beauty recipes and cuisine.

Palavras chave/Keywords:

Ovo; Medicina; Beleza; Culinária; Gastronomia.

Egg; Medicine; Beauty; Cooking; Food. 
Ovos, ovos, ovos e mais ovos. Pequeninos como os de codorniz, de tamanho normal - porque mais comuns - os de galinha, um pouco maiores os de pata e os de perua, enormes os de avestruz, para nos ficarmos no reino dos galiformes. Também podemos juntar os de criaturas mais exóticas como cobras, crocodilos e tartarugas. Simples ou pintados com motivos fitomórficos, zoomórficos ou outros, presentes na alimentação, em algumas mezinhas, em cosméticos e na decoração de ambientes domésticos, os ovos podem ser verdadeiros ou realizados em materiais tão diversos como madeira, pedra, vidro, cristal ou metais preciosos, com vista a aplicações diversas. Encontramo-los como modestos objectos de madeira destinados a coser meias, utilizados por gerações do passado, como pisa-papéis elegantes de pedras coloridas, de vidro e até de cristal, nos escritórios, como candeeiros de mesa de tamanhos variados, realizados em diversos materiais, como caixas de prata e como jóias magníficas, pensemos nas criações Fabergé. E o rol continua em permanente actualização.

\title{
1. O ovo: significado simbólico e significado real
}

\begin{abstract}
"Qual dos dois fosse o primeiro, o ovo ou a galinha, é questão que ninguém pode decidir". . Este antigo problema não escapou a Rafael Bluteau, na entrada "ovo" da sua obra Vocabulário Portuguez e Latino publicada entre 1712 e $1728^{2}$. Esta formulação levar-nos-ia muito longe, nomeadamente à criação do universo e de todas as criaturas, ao princípio da vida. No entanto, o que aqui se pretende é bem mais limitado, trata-se do simbolismo do ovo nas sociedades ocidentais. Nessa conformidade, em sentido lado, o ovo aparece como símbolo da vida, que contem os quatro elementos: a terra na casca, a água na clara, o fogo na gema e o ar no espaço entre a clara e a casca ${ }^{3}$.
\end{abstract}

1 BLUTEAU, Rafael - Vocabulario Portuguez e Latino, vol. 6, Lisboa: Oficina de Pascoal da Silva, 1720, p. 143.

2 Sobre este intelectual, cf. BRAGA, Isabel M. R. Mendes Drumond-D. Rafael Bluteau na Corte Portuguesa (1668-1734). Cultura, Religião e Quotidiano. Portugal (século XVIII). Lisboa: Hugin, 2005, p. 7-82.

3 BLUTEAU, Rafael - Vocabulario Portuguez e Latino..., cit., vol. 6, p. 143. 
O ovo pela sua forma e pelas suas características é associado às ideias de nascimento, renascimento e renovação cíclica daí ser comum a sua oferta na Páscoa, quer na actualidade - basta pensar nos numerosos ovos de chocolate produzidos em cada quadra pascal - quer no passado. Neste caso, a situação mais especial é constituída pelas peças de joalharia em forma de ovo, produzidas na Rússia por encomendas dos czares Alexandre III (1845-1894) e Nicolau II (1868-1918). Para a igreja ortodoxa, a Páscoa constitui um momento muito relevante do calendário litúrgico. No século XIX, já era comum a troca de ovos de galinha decorados e três beijos para festejar o momento. Pela Páscoa de 1885, o czar Alexandre III decidiu ir mais longe e encomendou ao joalheiro oficial da Corte - Karl Gustavovich Faberge, que adoptou o nome de Peter Carl Fabergé (São Petersburgo, 1846 - Lausanne, 1920), jovem com formação em vários espaços europeus, que aos 24 anos herdara do pai Gustavo Fabergé a casa de jóias formada em 1842 - uma jóia decorativa em forma de ovo para presentear a czarina Maria Feodorovna (1847-1929), de origem dinamarquesa e de nome inicial Dagmar. Foi a primeira de 56 encomendas (número estimado) entre 1885 e 1916, tendo a produção sido interrompida em resultado da revolução bolchevique (1917). Os ovos, produzidos em platina, ouro, prata, cobre, quartzo, jade ou lápis-lazúli e decorados com gemas diversas entre as quais diamantes, eram também sujeitos a técnicas de aplicação de esmalte. Cada ovo era uma peça única com decoração inspirada em obras de arte e cenas de história da Rússia. Ao abrir o ovo a presenteada encontrava uma surpresa: uma galinha, um coelho, uma coroa imperial, uma carruagem, um biombo e muitos outros motivos em miniatura, pois as peças tinham cerca de 13 centímetros. A prática iniciada por Alexandre III teve continuidade com o czar Nicolau II que, a partir de 1895, passou a encomendar dois ovos, um para sua mãe a czarina Maria Feodorovana e outro para a sua mulher Alexandra Feodorovna (1872-1918), de origem alemã e de nome inicial Alix von Hessen und Rhein. Os ovos Fabergé, actualmente espalhados por vários países, em colecções públicas e privadas, atingem preços elevadíssimos em leilões ${ }^{4}$.

\footnotetext{
4 Ovos Imperiais Fabergé < http://www.antiguidades.com.br/ovosimperiaisfaberge.htm > consultado a 19 de Julho de 2011; Ovos Imperiais Fabergé < http://www.girafamania.com. br/europeu/materia_russa_faberge.html > consultado a 19 de Julho de 2011.
} 
Simbólicas são também muitas das acepções do discurso proverbial. Enquanto elementos da cultura popular, os provérbios são relativamente atemporais no sentido em que aparecem como o resultado da antiga sabedoria, impondo-se, por isso, como argumento de autoridade, veiculando acepções tidas como verdadeiras para diferentes tempos e espaços, não obstante remeterem mais para o passado do que para o comportamento futuro 5 . Podem assumir o aspecto de sugestões, conselhos, avisos e regras práticas e caracterizam-se, de entre outros aspectos, por se apresentarem no tempo presente, expressando verdades sempre válidas ${ }^{6}$. Descrevem estados de coisas gerais, não admitindo leituras episódicas só compreensíveis num espaço ou num tempo. No entanto, se uns suscitam uma interpretação literal, outros desencadeiam a necessidade de uma interpretação figurada ${ }^{7}$. São textos curtos, com uma estrutura concisa, anónimos, ou melhor, da autoria da respectiva comunidade linguística e cultural, os quais fazem circular uma experiência colectiva ${ }^{8}$, o que não impede a semelhança de provérbios da autoria de comunidades diferentes ${ }^{9}$. Fixemo-nos nos provérbios relativos

5 MATTOSO, José - O Essencial sobre os Provérbios Medievais Portugueses. Lisboa: Imprensa Nacional-Casa da Moeda, 1987; COSTA, Hamilton - La Réprésentation du Corps dans la Littérature Populaire Portugaise: Le Discours Proverbial in Littérature Orale Tradicionalle Populaire. Actes du Colloque, Paris, [s.n.], 1987, p. 561-576; LOPES, Ana Cristina Macário - Texto Proverbial Português. Elementos para uma Análise Semântica e Pragmática. Coimbra: Dissertação de Doutoramento em Linguística Portuguesa apresentada à Faculdade de Letras da Universidade de Coimbra, 1992; VIANA, Mário - A Vinha e o Vinho nos Provérbios e na Cultura Popular, Revista da Biblioteca Nacional, 2. ${ }^{\mathrm{a}}$ série, vol. 8, n. ${ }^{\circ} 1$, Lisboa (1993) 7-22; BRAGA, Isabel M. R. Mendes Drumond - Castela e os Castelhanos nos Provérbios Portugueses. Cooperação e Conflito. Portugal, Castela e Aragão (séculos $X V$-XVII). Lisboa: Universitária Editora, 2002, p. 261-271.

6 SCHMIDT-RADEFELDT, Jurgen - Descrição Semântica e Funções Semanfóricas do Provérbio, Estudos de Linguistica Portuguesa, organização do mesmo e de José G. Herculano de Carvalho. Coimbra: Coimbra Editora, 1984, p. 216.

7 LOPES, Ana Cristina Macário - Texto Proverbial..., cit., p. 21.

8 SCHMIDT-RADEFELDT, Jurgen - Descrição Semântica..., cit., p. 213.

9 GHITESCU, Micaela - Os Provérbios - Traço de União entre Irmãos. Actas do I Congresso Internacional de Literaturas Lusófonas (= Nós. Revista de Lusofonia, n. ${ }^{\text {os }}$ 19-20), Pontevedra, Braga, 1991, p. 357-360; FUNK, Gabriela - O Provérbio como Ponte entre diferentes Culturas. Portugal, Indien und Deutschland. Portugal, Índia e Alemanha. Akten der V. Deutsch-Portugiesischen Arbeitsgespräche. Actas do V Encontro Luso-Alemão, coordenação de Helmut Siepmann, Köln, Zentrum Portugiesischsprachige Welt, Lisboa, Centro de Estudos Históricos da Universidade Nova de Lisboa, 2000, p. 345-353. 
ao ovo, a partir da compilação de António Delicado, publicada em $1651^{10} \mathrm{e}$ da realizada por Rafael Bluteau, no princípio do século XVIII ${ }^{11}$.

Comecemos por analisar os provérbios em que o ovo nos aparece como alimento, ou seja, aqueles em que o ovo tem um significado literal. "Um ovo há mister sal e fogo" ou, numa variante, "Um ovo quer sal e fogo" e "Lá vai o mal onde comem o ovo sem sal", numa clara alusão à preferência pelo ovo cozinhado e temperado em detrimento do ovo cru. No mesmo sentido, mas com mais requinte: "Ovo assado, meio; ovo cozido, ovo inteiro; frito, ovo e meio". Isto é, o provérbio dá conta de uma clara hierarquia na maneira de preparar o alimento. Por ordem decrescente: frito, cozido e assado. Em nenhum destes casos se associam os ovos ao açúcar. Curiosamente, parte destes entendimentos do senso comum tiveram tradução na prescrição médica. O médico Francisco da Fonseca Henriques, em obra publicada em 1721, fez saber que os ovos - referia-se aos de galinha - deveriam ser comidos com sal "não só porque excita o apetite mas também porque o sal emenda o lentor que têm os ovos, com o qual muitas vezes causam náuseas e enjoos de estômago"12. Já no que se refere às técnicas culinárias o mesmo autor sugere, por ordem decrescente, ovos escalfados, cozidos, assados e fritos e sempre de consistência branda ${ }^{13}$. Neste caso, o provérbio aparece-nos preconizando o contrário "Ovo brando, comer embaraçado", o que poderá também ter um significado simbólico distinto: atitudes pouco seguras ou falta de autoridade têm como consequência problemas. Finalmente, "Quem me dá um ovo não me quer morto", valoriza o papel nutricional do alimento.

Os restantes provérbios remetem para outros níveis de análise. A valorização dos ovos portugueses em detrimento dos ovos importados: "Ovo de Portugal não há mister sal"14; a faceta nutritiva do alimento:

${ }^{10}$ DELICADO, António - Adágios Portugueses reduzidos a Lugares Communs, nova edição revista e prefaciada por Luís Chaves. Lisboa: Livraria Universal, 1923, p. 93, 95, 126, 129, 137, 140, 144, 161-163, 200, 206.

${ }^{11}$ BLUTEAU, Rafael - Vocabulario Portuguez e Latino..., cit., vol. 6, p. 144-145. Bluteau apresenta todos os provérbios já compilados por Delicado e acrescenta mais alguns.

${ }^{12}$ HENRIQUES, Francisco da Fonseca - Anchora Medicinal para Conservar a Vida com Saude. Lisboa: Oficina da Música, 1721, cap. VIII, p. 177.

${ }^{13}$ HENRIQUES, Francisco da Fonseca - Anchora Medicinal..., cit., p. 177-178.

${ }^{14}$ Apesar de Portugal recorrer pontualmente à importação de ovos, também os exportou. Por exemplo, vendiam-se ovos, assim como galinhas, de Lagos para Cádis. Pelo menos há 
“A criado novo, pão e ovo; depois de velho, pão e Demo", tentando demonstrar a relação da qualidade do alimento e a força de trabalho dos mais jovens, um investimento não necessário face aos idosos. Por outro lado, "De mau corvo, mau ovo", fomenta a ideia da necessidade de possuir boas aves para obter bons ovos. Sentidos totalmente figurados apresentam os provérbios "Mal vai a raposa quando anda aos gritos e pior quando anda aos ovos" ou "Cacarejar e não pôr ovo". Ou seja, falta de discrição e alvoroço são perniciosos e recurso a alimentos não adequados só podem evidenciar problemas graves. No segundo caso, a frase denuncia o alarde e a falta de resultados, comuns aos que gostam de se evidenciar. Igualmente apresenta um sentido figurado o provérbio "A galinha aperta-lhe o ninho e pôr-te-á o ovo". Isto é, a pressão permite obter resultados.

Apesar de os foros, como veremos a seguir, não serem frequentemente compostos por ovos e, sobretudo, porque os ovos eram alimentos acessíveis, houve, mesmo assim, quem reclamasse do pagamento dos ditos foros preconizando que "De foro nem um ovo". Com sentido afim se apresenta "Não o tive pelo ovo, senão pelo foro". Na verdade, a frase pode ser vista em perspectivas diferenciadas ou o senhor exige o ovo, de valor irrisório, para manter o estatuto ou a exigência do senhor torna-se indigna da sua posição ${ }^{15}$. Por outro lado, "Deu-me Deus um ovo e esse goro" remete para benesses recebidas e frustrações. Nestes casos, os ovos não se apresentam como alimentos desejados ou portadores de especial importância. "Cheio como um ovo", não apresenta dificuldade de interpretação, enquanto "Parece que saiu da casca do ovo" se refere a alguém que começa a evidenciar vontade própria. "Ao frigir dos ovos o vereis" remete para a necessidade de, atempadamente, as pessoas se prevenirem para o que lhes possa acontecer, de modo a não serem apanhadas de surpresa. Apesar de os ovos não serem exactamente produtos sazonais, "Rainha é a galinha que põe ovos na vindima", não deixa de valorizar a ave que em Setembro dava ovos.

$\mathrm{Na}$ actualidade, não podemos deixar de lembrar que, certas pessoas, para diminuírem outras sem grandes habilidades não deixam de utilizar a frase

registo de tal ter acontecido em Junho de 1791. Cf. PAULA, Glória de Santana - Lagos (1745-1792). Dinâmicas Económicas e Elites de Poder. Lisboa: Estar, 2001, p. 32.

15 Tais são os entendimentos de MATTOSO, José - O Essencial sobre..., cit., p. 19-20. 
"nem sabe fritar um ovo"16, o que nos remete para a pouca importância e para o primarismo do acto, em termos do senso comum.

Do ponto de vista da prática alimentar quotidiana, os ovos tiveram um papel importante em termos nutricionais. Mas, paralelamente a esta função, não deixaram de apresentar um significado simbólico. Se é um facto que em todos os meios sociais se consumiram ovos, também não deixa de ser verdade que nem todos os preparavam da mesma maneira. Mais do que isso, em certos momentos, e em determinados espaços, estiveram ligados à alimentação dos dias de jejum e abstinência, isto é, aos pratos consumidos nos dias magros. Recordemos que se aos católicos - ao contrário do que se passou com os judeus e com os muçulmanos - não se interditaram alimentos, também é certo que alguns foram proibidos em determinados momentos do calendário litúrgico, nomeadamente nas épocas que antecediam as grandes solenidades religiosas. Efectivamente, o jejum católico é herdeiro da prática judaica e está presente nas Sagradas Escrituras, apresentando-se como um elemento de piedade que foi adoptado como rito penitencial, apoio e complemento da oração, súplica ao divino e preparação do reencontro entre o humano e o sagrado, no entendimento da Igreja. Se em sentido literal, o jejum significa a abstinência do consumo alimentar durante um determinado tempo, na prática, acabou por se assumir apenas como ausência do consumo de carne e, por vezes, também de lacticínios e de ovos. Ou seja, de carne e de outras substâncias animais, o que indirectamente valoriza a carne na alimentação do passado ${ }^{17}$.

Qual foi a prática corrente em termos dos dias de jejum? Abstinência apenas da carne, que se substituía por peixe, ou também dos ovos e lacticí-

${ }^{16}$ Vejam-se as reflexões que a frase suscitou a DAVIDSON, Alan - The Oxford Companion to Food, 2. ${ }^{\text {a }}$ edição. Oxford: Oxford University Press, 2006, p. 269.

${ }^{17}$ Sobre os jejuns, cf. FLANDRIN, Jean-Louis - L'Ordre des Mets. Paris: Editions Odile Jacob, 2002, p. 44-46; LAURIOUX, Bruno - Manger au Moyen Age. Pratiques et Discours Alimentaires en Europe au XIV et $X V^{E}$ siècles. Paris: Hachette, 2002, p. 103-116; VANESSE, Claude - Le Jeûne dans les Débats Confessionels au XVI siècle in Le Boire et le Manger au $X V T^{e}$ siècle, Saint-Etienne: Publications de l'Université de Saint-Etienne, 2004, p. 237-252; MONTANARI, Massimo - La Fame e l'Abbondanza. Storia dell'Alimentazione in Europa, 5. ${ }^{a}$ edição. Roma: Bari, Laterza, 2005, p. 98-103; FERRIÈRES, Madeleine - Nourritures Canailles. Paris: Editions du Seuil, 2007, p. 187-188; QUELLIER, Florent - La Table des Français. Une Histoire Culturelle (XV'-début du XIX $X^{e}$ siècle). Rennes: Presses Universitaires de Rennes, 2007, p. 126-132. 
nios? A resposta passa pelo conhecimento do maior ou menor rigor dos bispos nas dioceses. Consequentemente, já se vislumbra que se verificaram variações muito significativas. Se em algumas obras de culinária francesa da Época Moderna, os ovos aparecem a integrar as entradas e as receitas de ovos para dias magros são mais numerosas do que as que contemplam os dias gordos ${ }^{18}$, em algumas dioceses francesas e de outros Reinos, o consumo de ovos ou foi prescrito ou objecto de dispensa ${ }^{19}$. Em Portugal, por exemplo, sabe-se que os ovos chegaram a ser objecto de restrições. As constituições sinodais do bispado de Coimbra, de 1591, proibiam que, na Quaresma, se apregoassem ovos, assim como leite, manteiga e queijos frescos. O mesmo documento vedava o consumo de tais produtos nos dias de jejum nos portos de $\operatorname{mar}^{20}$. No entanto, no convento de Nossa Senhora dos Remédios, de Braga, em 1637, o visitador D. Sebastião de Matos de Noronha, ordenou que nos dias de maior penitência (quartas, sextas e sábados), a abadessa mandasse providenciar cação, bacalhau e outros peixes secos para evitar atitudes relaxadas, mais advertindo que "quando não houver peixe fresco na terra em presso que caiba na ração que se da em dinheiro às religiozas e quando falte tudo haja provizão de ovos para que com dous ovos e hũas ervas guizadas com charidade e amor possão passar e às noites se lhes dará sempre pello menos hum ovo com hum piqueno de queijo ou fruta quando houver"21. Idêntico problema se verificou no convento do Salvador, de Braga, no mesmo $a_{0}{ }^{22}$. Nos conventos franciscanos de Santa Clara, do Porto ${ }^{23}$,

${ }^{18}$ FLANDRIN, Jean-Louis - L'Ordre des Mets..., cit., p. 44-46

${ }^{19}$ QUELLIER, Florent - La Table des Français..., cit., p. 126-132.

${ }^{20}$ OLIVEIRA, António de - A Vida Económica e Social de Coimbra de 1537 a 1640, primeira parte, vol. II. Coimbra: Universidade de Coimbra, Faculdade de Letras, Instituto de Estudos Históricos Dr. António de Vasconcelos, 1972, p. 343.

${ }^{21}$ Braga, Arquivo Distrital de Braga (A.D.B.), Visitas e Devassas, liv. 19, fol. 22v. Cf. BRAGA, Isabel M. R. Mendes Drumond - Vaidades nos Conventos Femininos ou das Dificuldades em deixar a Vida Mundana (séculos XVII-XVIII). Revista de História da Sociedade e da Cultura, vol. 10, tomo 1, Coimbra (2010) 305-322. Disponível no endereço $<\mathrm{http}: / /$ www.uc.pt/chsc/rhsc/rhsc_10>.

${ }_{22}$ Braga, A.D.B., Visitas e Devassas, liv. 30, fol. 24v. Cf. BRAGA, Isabel M. R. Mendes Drumond - Vaidades nos Conventos Femininos..., cit.

${ }^{23}$ FERNANDES, Maria Eugénia Mata - O Mosteiro de Santa Clara do Porto em meados do século XVIII. Porto: Arquivo Histórico, Câmara Municipal do Porto, 1992, p. 182. 
e da Encarnação, do Funchal24, o peixe podia igualmente ser substituído pelos ovos durante a Quaresma, no século XVIII.

Na cadeia da Junqueira, em Lisboa, estabelecimento onde se encontravam presos políticos, durante a segunda metade do século XVIII, nos dias de peixe os nobres eram agraciados com três ovos e os não nobres com dois. Posteriormente, os ovos foram substituídos por quantias monetárias, o que valeu a um dos detidos, o seguinte comentário "com isso nos deram um grande alívio, porque juntamente nos ficou cedida licença para empregarmos esse pequeno cabedal em outras coisas que mais nos satisfizessem"25.

Por outro lado, recorde-se que as chamadas bulas da cruzada, que possibilitavam aos fiéis que as adquirissem ficarem desobrigados da abstinência pascal de carne, ovos, leite e gorduras animais foram comuns e constituíram uma fonte de receitas para a Igreja ${ }^{26}$ quer em Portugal continental quer nas colónias, veja-se o caso concreto ocorrido no Rio de Janeiro. Apesar de os ovos serem comuns, momentos houve em que se verificaram faltas, notadas inclusivamente por homens da Igreja. Por exemplo, o bispo do Rio de Janeiro, D. José Caetano da Silva Coutinho, em pastoral de 8 de Março de 1811, fez saber que os colonos careciam de verduras, lacticínios e ovos. No mesmo documento tornou claro que era preferível permitir dispensas alimentares na Quaresma do que ver os católicos afastarem-se dos princípios da Igreja. Mais acrescentou que no seu bispado, nos dias de abstinência, era aceite o consumo de ovos e lacticínios, nomeadamente manteiga, a par de unto de vaca, de porco e toucinho para temperar já que não se produzia azeite ${ }^{27}$.

${ }^{24}$ GOMES, Eduarda Maria de Sousa - O Convento da Encarnação do Funchal. Subsídios para a sua História (1660-1777). Funchal: Secretaria Regional do Turismo e Cultura, Centro de Estudos de História do Atlântico, 1995, p. 133.

${ }^{25}$ PORTUGAL, D. João de Almeida - As Prisões da Junqueira durante o Ministério do Marquês de Pombal escritas ali mesmo pelo Marquês de Alorna, uma das suas vítimas, publicadas conforme o original, por José de Sousa Amado, presbitero secular, conforme a primeira edição de 1857. Lisboa: Frenesi, 2005, p. 30.

${ }^{26}$ BRAGA, Paulo Drumond - Igreja, Igrejas e Culto in Portugal da Paz da Restauração ao Ouro do Brasil, coordenação de Avelino de Freitas de Meneses (=Nova História de Portugal, direcção de Joel Serrão e A. H. de Oliveira Marques, vol. 7). Lisboa: Presença, 2001, p. 112.

${ }^{27}$ ALGRANTI, Leila Mezan - 'Dias Gordos' e 'Dias Magros': Calendário Religioso e Práticas Alimentares Católicas em São Paulo e Rio de Janeiro (séculos XVIII e XIX) in A Igreja no Brasil. Normas e Práticas durante a Vigência das Constituições Primeiras do 


\section{O ovo na economia de outrora}

Os ovos eram caros ou baratos? Os seus preços foram sofrendo alterações relativas face a outros alimentos? Quem podia consumir ovos? Na falta de um levantamento dos preços dos géneros alimentares ao longo dos tempos, apenas temos dados pontuais para determinados momentos. Por exemplo, segundo A. H. de Oliveira Marques, o preço dos ovos terá aumentado quatro vezes de meados do século XII a meados do século XIII, acompanhando, aliás, a tendência das galinhas e dos coelhos. Aumentaram mais do que os patos (estes, duas vezes) e menos do que os pombos (seis vezes) ${ }^{28}$. Em 1524, D. João III, seus irmãos e capelães consumiram 1.364 ovos em 22 dias, isto é, mais de 113 dúzias, as quais custaram 20 reais cada uma ${ }^{29}$. Na década de 30 do século XVI, cada dúzia ascendia a preços entre os 46 e os 50 reais $^{30}$. No Funchal, em 1732, um ovo custava cinco réis e, consequentemente, uma dúzia, $60^{31}$. Mais tarde, em 1796, no Porto, um ovo custava pouco mais de 3 réis e uma dúzia ficava-se pelos 40 réis $^{32}$. Nesse mesmo ano, Carrère, um estrangeiro que visitou Lisboa, afirmou que então uma dúzia de ovos se obtinha a troco de 180 réis $^{33}$, mais de o quadruplo da quantia antes referida, o que demonstra o habitual e distorcido olhar dos estrangeiros, embora não seja de excluir que, em Lisboa, os ovos fossem mais caros do que no Porto. Tendo em conta o valor nutricional do ovo uma realidade parece clara ao

Arcebispado da Bahia, organização de Bruno Feitler e Evergton Sales Souza. São Paulo: Editora Unifesp, 2011, p. 276 e 279.

${ }^{28}$ MARQUES, A. H. de Oliveira - A Circulação e a Troca de Produtos in Portugal em Definição de Fonteiras (1096-1325). Do Condado Portucalense à Crise do Século XIV, coordenação de Maria Helena da Cruz Coelho e Amando Luís de Carvalho Homem (= Nova História de Portugal, direcção de Joel Serrão e A. H. de Oliveira Marques, vol. 3). Lisboa: Presença, 1996, p. 521.

${ }^{29}$ SANTOS, Maria José Azevedo - Jantar e Cear na Corte de D. João III, leitura, transcrição e notas de dois Livros de Cozinha do Rei (1524 e 1532). Vila do Conde, Coimbra, [s.n.], 2002, p. 41.

${ }^{30}$ SANTOS, Maria José Azevedo - A Escrita serve à Mesa in Saberes e Sabores. Actas. Chaves: Delegação Regional de Cultura do Norte, 2006, p. 28-29.

${ }^{31}$ GOMES, Eduarda Maria de Sousa - O Convento da Encarnação do Funchal..., cit., p. 133.

${ }^{32}$ FERNANDES, Maria Eugénia Mata - O Mosteiro de Santa Clara do Porto..., cit., p. 178 .

${ }^{33}$ CARRÈRE, J. B. F. - Panorama de Lisboa no ano de 1796, tradução, prefácio e notas de Castelo Branco Chaves. Lisboa: Biblioteca Nacional, 1989, p. 97. 
longo dos tempos: era bem mais barato consumir ovos do que carne ou peixe, em especial se tivermos em conta os peixes mais apreciados, tais como linguados e salmonetes. Aliás, já no século XVI, Gil Vicente considerara que os ovos eram os produtos alimentares mais acessíveis que se podiam encontrar, referindo-se especialmente aos de pata ${ }^{34}$.

Através dos contratos de exploração agrária podemos verificar que as terras não cultivadas pelos seus donos podiam ser objecto de cedência a terceiros através de três tipos de contratos: arrendamentos (por anos), emprazamentos (por vidas) e aforamentos (perpétuos). Os arrendamentos eram contratos breves que permitiam uma grande flexibilidade de gestão, podendo os senhores alterar o modo de exploração dos bens, a duração dos prazos e a natureza e o montante das rendas. Levavam a um esgotamento rápido e à não realização de melhorias por parte dos foreiros. Os aforamentos eram bons para os foreiros pois as benfeitorias que fizessem beneficiavam os seus descendentes. Não permitiam actualizar rendas e, consequentemente, eram raros. Só eram utilizados para arrotear terras e secar terrenos pantanosos. O tipo de contrato dominante era o de aforamento. Era um contrato mais equilibrado. Podia ser de uma a quatro vidas (as vidas dos foreiros propriamente ditas). $\mathrm{O}$ mais comum era a realização de contratos de três vidas. Por exemplo, os membros do casal e um filho. Quando se passava de uma vida para outra pagava-se a lutuosa (igual a um foro). Independentemente do tipo de contrato, o foreiro ficava obrigado ao pagamento de um foro, a renda senhorial, o qual era composto por uma parte principal, o cânon e por uma parte secundária, as direituras, foragens ou miúnças.

O cânon podia ser solvido em numerário ou em géneros, constituir uma quantia fixa ou uma percentagem de colheita (quota parciária). As direituras eram pagas em diversos artigos como vinho, azeite, pão, galinhas, cereais, ovos, queijos, mel, cera, gado, de entre outros, ou pequenas quantias em

${ }^{34}$ No Auto de Mofina Mendes pode ler-se a respeito da feira de Trancoso: "Do que este azeite render/ comprarei ovos de pata, que é a cousa mais barata qu'eu de lá posso trazer. E estes ovos chocarão; / cada ovo dará um pato,/ e cada pato um tostão,/ que passará de um milhão/ e meio, a vender barato". Cf. Gil Vicente, Copilaçam de Todalas Obras de Gil Vicente, introdução e normalização do texto de Maria Leonor Carvalhão Buescu, vol. 1, Lisboa, Imprensa Nacional-Casa da Moeda, 1983, p. 115. 
dinheiro. Em Portugal predominaram as rendas em géneros e em montantes fixos no que respeita às zonas rurais. Nas zonas periurbanas as rendas em dinheiro eram muito comuns, tal como em lugares mais distantes dos senhorios dificilmente controláveis e cujos produtos não se transportavam com facilidade ${ }^{35}$.

Pelos muitos contratos que se conservaram e que foram objecto de estudo, na Idade Média e na Idade Moderna, as direituras, miúnças ou foragens complementavam os cânones que os arrendatários deviam aos proprietários das terras, com eles constituindo a renda senhorial. Nas partes secundárias das rendas, os ovos ocupavam o seu lugar, embora com pouco relevo. Assim, por exemplo, nos séculos XIV e XV, 8,2\% das direituras recebidas pelo mosteiro de Alcobaça, um dos mais ricos de Portugal, eram compostas por ovos e peles de animais ${ }^{36}$. Na mesma época, em zonas tão diferentes como a região de Loures $^{37}$ e a encosta ocidental da Serra da Estrela ${ }^{38}$, os ovos achavam-se em terceiro lugar na lista das direituras.

Outros exemplos: em 1459, quatro casais situados na actual freguesia de São Paulo de Frades, concelho de Coimbra, então pertencentes ao mosteiro de São Paulo de Almaziva, deviam-lhe, cada um, pelo São Martinho, dois capões, uma dúzia de ovos e outra de pães alvos brancos ${ }^{39}$. Em 1506,

${ }^{35}$ MARREIROS, Maria Rosa Ferreira - Os Proventos da Terra e do Mar in Portugal em Definição de Fonteiras (1096-1325). Do Condado Portucalense à Crise do Século XIV, coordenação de Maria Helena da Cruz Coelho e Amando Luís de Carvalho Homem (= Nova História de Portugal, direcção de Joel Serrão e A. H. de Oliveira Marques, vol. 3). Lisboa: Presença, 1996, p. 464; MARQUES, A. H. de Oliveira - Portugal na Crise dos Séculos XIV e XV (= Nova História de Portugal, direcção de Joel Serrão e A. H. de Oliveira Marques, vol. 4). Lisboa, 1986, p. 91-92; RODRIGUES, Ana Maria S. A. - A Propriedade Rural in Portugal do Renascimento à Crise Dinástica, coordenação de João José Alves Dias (= Nova História de Portugal, direcção de Joel Serrão e A. H. de Oliveira Marques, vol. 5). Lisboa: Presença, 1998, p. 97-99.

${ }^{36}$ GONÇALVES, Iria - O Património do Mosteiro de Alcobaça nos Séculos XIV e XV. Lisboa: Universidade Nova de Lisboa, Faculdade de Ciências Sociais e Humanas, 1989, p. 295.

${ }^{37}$ OLIVEIRA, José Augusto da Cunha Freitas de - Organização do Espaço e Gestão de Riquezas. Loures nos Séculos XIV e XV. Lisboa: Universidade Nova de Lisboa, Centro de Estudos Históricos, 1999, p. 117.

${ }^{38}$ PINA, Isabel Castro - A Encosta Ocidental da Serra da Estrela. Um Espaço Rural na Idade Média. Cascais: Patrimonia, 1998, p. 106-107.

${ }^{39}$ SANTOS, Maria José Azevedo - Vida e Morte de um Mosteiro Cisterciense. S. Paulo de Almaziva (Séculos XIII-XVI). Lisboa: Colibri, 1998, p. 301. 
na sua comenda de Montalvão, a Ordem de Cristo recebia um total de 138 ovos em direituras de propriedades arrendadas, onde predominavam as vinhas ${ }^{40}$. Em 1521, os rendeiros do mosteiro de São João de Tarouca pagavam-lhe 125 ovos, a par de 193 galinhas, 34 marrãs, 21 carneiros, 12 cabritos e outros animais ${ }^{41}$.

Para bastante mais tarde, temos dados referentes ao mosteiro lisboeta de São Vicente de Fora. Em 1678, recebeu um total de 110 ovos. Cerca de um século depois, em 1776, essa quantia desceu para 51, subindo para 63 em 1791, mas note-se que em ambos os casos tal apenas se refere a um único local de proveniência, São Julião do Tojal ${ }^{42}$. Por outro lado, a quinta da Agualva, pertencente ao convento de São João Evangelista de Xabregas, em Lisboa, devia-lhe 24 ovos em 1718, 12 em 1767 e 24 em 1799. Na mesma congregação, mas na Colegiada do Salvador, de Vilar de Frades, os seus rendeiros entregavam-lhe, em 1821, 48 ovos $^{43}$.

Ao longo dos tempos, muito especialmente antes das actuais possibilidades da refrigeração e do embalamento a vácuo, as pessoas sempre demonstraram grande preocupação em conservar os alimentos, para que, na época em que os não havia frescos, os mesmos se pudessem consumir num estado diferente. As soluções passaram pela secagem das frutas, com a obtenção de passas de ameixa, maçã, marmelo, pêra, pêssego e uva; pela conservação das frutas através da realização de doces e geleias, pela salga e secagem de peixe e de carne, neste caso com a produção de buchos, chouriços, linguiças, morcelas, presuntos e salsichas; e ainda pela utilização de achar, isto é, uma espécie de pickles; de salmoiras para peixe, toucinho e queijo, sem esquecer que este último também se mantinha em azeite e também se secava. Ou seja, dentro das possibilidades existentes procurava-se a preservação de carne,

${ }^{40}$ Tombos da Ordem de Cristo, vol. 1 (Comendas a Sul do Tejo. 1505-1509), organização e revisão geral de Iria Gonçalves, Lisboa: Universidade Nova de Lisboa, Centro de Estudos Históricos, 2002, p. 49-58.

${ }^{41}$ COELHO, Maria Helena da Cruz - S. João de Tarouca em Tempos de Quinhentos in Homens, Espaços e Poderes. Século XI-XVI, vol. 2 (Domínio Senhorial). Lisboa: Horizonte, 1990, p. 178.

${ }^{42}$ COELHO, Maria de Fátima - Bens Eclesiásticos. Crúzios in Dicionário de História da Igreja em Portugal, direcção de A. A. Banha de Andrade, vol. 2. Lisboa: Resistência, 1983, p. 647.

${ }^{43}$ COELHO, Maria de Fátima - Bens Eclesiásticos. Lóios in Dicionário de História da Igreja em Portugal..., cit., vol. 2, p. 667 e 672. 
peixe, frutos, legumes e queijos. Cabe perguntar como se procedia face aos ovos. Na verdade, os ovos não eram sazonais como os frutos, os legumes ou os queijos, nem se obtinham em quantidades que importasse guardar para épocas de menos recursos. Ou seja, nada se fez para os manter, uma vez que eram relativamente acessíveis e se podiam obter durante todo o ano. Estas realidades seculares só se viam ameaçadas em tempos de guerra.

Durante a II Guerra Mundial (1939-1945), tal como em outros momentos de conflitos bélicos do passado, as carências alimentares abrangeram quer as tropas quer as populações em geral. Fome e guerra eram e continuam a ser aliadas. Às restantes preocupações juntaram-se as de nutrir as pessoas e, em tempo de guerra, novas práticas dietéticas se foram impondo. Foi neste contexto que a Inglaterra dos anos 40 produziu ovos em pó. A introdução do novo produto, tão necessário quanto desconhecido, foi acompanhado por panfletos explicativos destinados à população. Havia que ensinar a utilizar os ovos em pó, bem melhores em massas do que para consumo em cru. Fazia saber-se que, apesar da textura e do sabor não serem os dos ovos frescos, em termos nutricionais juntar uma colher de pó de ovo a duas colheres de água correspondia a um ovo fresco ${ }^{44}$. Os ovos em pó nasceram de uma necessidade premente em tempo de guerra e, posteriormente, foram incluídos em muitos preparados industriais, como massas, bolachas e bolos, sendo hoje comuns especialmente em pastelaria.

\section{O ovo: mezinha e cosmético}

Ao longo dos tempos, as teorias médicas foram dando alguma importância ao ovo enquanto alimento que poderia integrar as dietas alimentares dos indivíduos sãos e das pessoas doentes. Se bem que, por exemplo, açúcar e marmelada pudessem ser considerados alimentos prescritos como fármacos que reforçavam a dieta de acordo com as concepções hipocrático-galénicas ainda em vigor, no entendimento de então, os ovos raramente tiveram tal estatuto, apesar de serem entendidos como benéficos para os debilitados.

${ }^{44}$ Eating for Victory. Healthy Home Front Cooking on War Ration. Reproductions of Official Second World War Instruction Leaflets, prefácio de Jill Norman. Londres: Michael O’Mara Books Limited, 2007, p. 7, 13. 
Assim se compreende a fraca representatividade dos ovos nas dietas alimentares dos enfermos quer nos hospitais normais quer nos de recobro, especialmente em épocas mais recuadas. Mesmo assim, alguns casos ficaram documentados.

Para o século XVI, sabemos que os ovos entravam, ainda que muito marginalmente, na dieta alimentar dos doentes internados. Assim, o regimento do Hospital de São Lázaro, de Coimbra, outorgado, em 1502, por D. Manuel I, mandava que fossem dados aos enfermos ovos provenientes de foros $^{45}$. Igualmente no início do século XVI, no Hospital Real, das Caldas, os ovos entravam na ceia dos enfermos, a mais frugal das refeições. Estavam ausentes do jantar mas, no caso dos doentes mais fracos, que tinham direito a mais duas refeições, almoço e merenda, integravam esses repastos conjuntamente com conservas e vinho. Às sextas-feiras, quando se verificavam faltas de uvas e passas também eram consumidos ${ }^{46}$. Mais tarde, por volta de 1610, caldos de galinhas com gemas de ovos eram os pratos consumidos ao almoço dos que se achavam mais fracos, no Hospital Real de Todos os Santos, de Lisboa ${ }^{47}$. Por outro lado, entre Outubro de 1764 e Junho de 1765, no Hospital da Convalescença, de Coimbra, gastaram-se 120 réis em ovos, o que representou apenas $0,08 \%$ do total das despesas com a alimentação dos doentes. Uma percentagem muito baixa em termos absolutos e irrisória se tivermos em perspectiva outros géneros. Basta comparar com as frangas e as galinhas, com as quais se despenderam 63.925 réis, ou seja, $41,2 \%$ do tota ${ }^{48}$. Um pouco melhor representados estavam os ovos na dieta dos doentes do Hospital Real, das Caldas, uma vez que entre 1749 e 1774, representaram 5\% das despesas alimentares ${ }^{49}$. No século XIX,

${ }^{45}$ OLIVEIRA, António de - A Vida Económica e Social de Coimbra ..., cit., vol. II, p. 354.

${ }^{46}$ RODRIGUES, Lisbeth de Oliveira - Os Géneros Alimentares de um Hospital Quinhentista: o Caso do Hospital das Caldas em Vida da Rainha D. Leonor in De Portas Adentro. Comer, Vestir, Habitar (ss. XVI-XIX). Coimbra: Imprensa da Universidade de Coimbra, Valladolid, Secretariado de Publicaciones e Intercambio Editorial, 2010, p. 57.

${ }^{47}$ LEMOS, Maximiano de - História da Medicina em Portugal. Doutrinas e Instituições, 3. a edição, vol. 1. Lisboa: Dom Quixote, Ordem dos Médicos, 1991, p. 138.

${ }^{48}$ LOPES, Maria Antónia - Pobreza, Assistência e Controlo Social. Coimbra (1750-1850), vol. 1. Viseu: Palimage, 2000, p. 656.

${ }^{49}$ RODRIGUES, Isabel Maria Pereira - Doença e Cura: Virtude do Hospital Real das Caldas (1706-1777). Lisboa: Dissertação de Mestrado em História Moderna apresentada à Faculdade de Letras da Universidade de Lisboa, 2007, p. 112. 
a situação parece ter conhecido alterações, pelo menos em alguns espaços como o Hospital da Misericórdia, de Vila Viçosa, embora se desconheça a percentagem que os ovos ocupavam nos gastos da alimentação destinada aos enfermos $^{50}$. Estas realidades não constituíram especificidades portuguesas. Por exemplo, na Época Medieval, no Hospital de Las Huelgas, de Burgos, os ovos substituíram o peixe, em alguns dias ${ }^{51}$, enquanto no século XVII, a dieta fornecida aos convalescentes internados no Hospital dos Peregrinos, de Nápoles, não contava com ovos, ao contrário do que acontecia com as refeições fornecidas pela instituição aos peregrinos, com excepção das dos dias quaresmais ${ }^{52}$. Ainda no que se refere aos enfermos, note-se que as dietas alimentares dos cativos estantes em poder dos muçulmanos, os quais eram objecto de resgate pelos padres da Ordem da Santíssima Trindade ao longo do século XVIII, compreendiam quantidades significativas de ovos, uns para serem ingeridos e outros eventualmente para aplicações tópicas, em especial para enfermidades de olhos, para todos os que adoeciam após o resgate e durante a viagem de regresso a Portugal ${ }^{53}$.

Se pensarmos que entre os mais fracos se contam os enfermos, mas também as crianças e as mulheres que amamentavam, tentemos verificar o que se entendia face a estes grupos, através de textos diversificados. Comecemos pelas crianças. Por exemplo, em 1734, Martinho de Mendonça de Pina e Proença nos seus Apontamentos para a Educação de hum Menino Nobre fez saber de forma muito sóbria que "lacticínios e ovos frescos são alimentos muito próprios para a primeira idade" ${ }^{54}$, dando continuidade a ideias defendidas antes. Por seu lado, a partir do século XVII, os chamados

${ }^{50}$ ARAÚJO, Maria Marta Lobo de - A Misericórdia de Vila Viçosa de finais do Antigo Regime à República. [s.1.]: Santa Casa da Misericórdia de Vila Real, 2010, p. 187-200.

${ }^{51}$ TOMÁS PÉREZ, Magdalena Santo - El Uso Terapéutico de la Alimentación en la Baja Edad Media in Alimentar la Ciudad en la Edad Media. Logroño: Instituto de Estudios Riojanos, 2009, p. 459-490.

${ }^{52}$ SALVEMINI, Raffaella - Il Consumo Alimentari negli Ospedali Napoletani: Aspetti e Problemi di un Approccio Economico (secc. XVI-XVIII) in Alimentazione e Nutrizione secc. XIII-XVIII, direcção de Simonetta Cavaciochi. Florença: Le Momnier, 1997, p. 851-866.

${ }^{53}$ LÁZARO, António - Bacalhau e Doces de várias Castas: sustento e regalos no Resgate Geral de Argel de 1754. Comunicação apresentada ao colóquio O Tempo dos Alimentos e os Alimentos no Tempo: Olhares sobre a Alimentação através da História, mas não publicada nas actas.

${ }^{54}$ PROENÇA, Martinho de Mendonça de Pina e - Apontamentos para a Educação de hum Menino Nobre. Lisboa: José António da Silva, 1734, p. 8. 
espelhos de príncipes - obras de teoria política destinadas a educar os futuros monarcas, nas quais se valorizava a defesa da fé e do bem comum, a liberalidade (isto é, a obrigação moral de dar, de fazer mercês), a justiça, a prudência, a clemência e a misericórdia, não deixavam de fazer considerações sobre a natureza do poder, ao reflectirem sobre as características de uma boa governação - começaram a incluir outros dados relevantes acerca da criação dos jovens desde a puerícia até à idade adulta. Neste contexto, couberam reflexões acerca do consumo de ovos. Por exemplo, Manuel da Silva Leitão, na Arte da Vida, ou Vida com Arte, publicada em 1738, mostrouse contrário aos doces de ovos em particular após lautos pratos de carne, ao considerar que não havia "maior perdição" do que comer ovos-moles ou "ainda de qualquer sorte encapelados, dizendo que a este prato por mais rico ninguém perdoa" após uma refeição pesada de carnes guisadas, cozidas ou assadas, o resultado poderia ser "boca de mel, coração de fel"55.

As mulheres que amamentavam sempre se preocuparam em fazer aumentar o leite, sendo diversos os recursos, desde regimes alimentares baseados no quente e no húmido (por exemplo, caldos de galinha, gemas de ovos, lacticínios, amêndoas e pinhões ${ }^{56}$, passando pelo apelo ao divino. $\mathrm{Na}$ Casa Real portuguesa, D. Águeda Maria Cardosa, foi ama da Princesa D. Isabel Luísa Josefa, filha de D. Maria Francisca Isabel e do regente D. Pedro. A preocupação com a criação da primogénita do casal foi visível nos cuidados postos na alimentação da ama antes e durante o período de aleitação. Entre os alimentos que compunham o regime da ama contavam-se: galinha, carneiro, toucinho, frutas e legumes diversos e um pratinho de ovos doces $^{57}$. Não podemos esquecer que a ama-de-leite, ao fornecer o alimento à criança, estava a ser responsável pela sua saúde presente e futura ${ }^{58}$.

${ }^{55}$ SILVA, Manuel Leitão da - Arte com Vida, ou Vida com Arte. Lisboa Ocidental: António Pedroso Galrão, 1738, p. 162.

${ }^{56}$ Sobre esta matéria, cf. BRAGA, Paulo Drumond - Leite. Biografia de um Género Alimentar. Sintra: Colares Editora, 2004.

${ }^{57}$ BRAGA, Isabel M. R. Mendes Drumond, BRAGA, Paulo Drumond - Duas Rainhas em Tempo de Novos Equilíbrios Europeus. Maria Francisca Isabel de Saboia. Maria Sofia Isabel de Neuburg. [Lisboa]: Círculo de Leitores, 2011, p. 185-186.

${ }^{58}$ PALMER, María del Carmen Simón - El Cuidado del Cuerpo de las Personas Reales: de los Médicos a los Cocineros en el Real Alcázar in Le Corps dans la Société Espagnole des $X V I^{e}$ et XVII siècles. Colloque International, dir. de Agostin Redondo. Paris: Publications de la Sorbonne, 1990, p. 120. 
Os ovos também aparecem ligados às práticas mágicas. As adivinhações serviam para saber o paradeiro de pessoas desaparecidas e de bens roubados e ainda para prever o futuro dos que procuravam as feiticeiras. Muitas adivinhações utilizavam a água como recurso ritual. Nela se lia o que se pretendia saber, sobretudo se à mesma se juntassem outros produtos tais $\operatorname{como~ovos}^{59}$, azeite, cardo, cevada, farinha e sal ${ }^{60}$. Aágua funcionava, assim, como um espelho revelador do agente dos malefícios, ou da situação de uma determinada pessoa ou alma, uma vez que a conjugação dos elementos simbolicamente valorizados, ao misturarem-se assumiam formas diversas susceptíveis de interpretação. Veja-se o caso, por exemplo, dos que lançavam ovos - clara e gema - na água e recitavam diversas palavras entendendo que apareceriam figuras que revelariam o que desejavam saber. Caso interessante, entre muitos, é o de certa feiticeira que tentou adivinhar se um seu cliente do sexo masculino tinha ou não ingerido peçonha para, a partir daí, estabelecido o diagnóstico, poder propor uma cura. Segundo as palavras do denunciante, a feiticeira "tomou um alguidar cheio de água e lhe lançou três ovos dizendo a ele declarante que se um daqueles ovos saltasse para o ar e voltasse a cair no dito alguidar era sinal que lhe tinham dado peçonha" ${ }^{61}$.

Na Idade Média, recorria-se a ovos com fins terapêuticos. Consta que a Rainha D. Isabel de Aragão, viúva de D. Dinis, estancou o sangue das feridas de um leproso usando uma clara de ovo, revelando conhecimento das propriedades hemostáticas da clara do ovo ${ }^{62}$. Num tratado médico português do século XV, feito a partir de obras de Galeno, Hipócrates, Avicena, Frei Gil de Santarém e muitos outros, claras e gemas de ovos entraram na preparação de unguentos destinados à cura de doenças tão diferentes como chagas (palavra genérica que designava ferimentos diversos, desde os que

${ }^{59}$ BETHENCOURT, Francisco - O Imaginário da Magia, Feiticeiras, Saludadores e Nigromantes no século XVI, Lisboa, 1987, p. 37-39; PAIVA, José Pedro-Práticas e Crenças Mágicas. O Medo e a Necessidade dos Mágicos na Diocese de Coimbra (1650-1740). Coimbra: Minerva, 1992, p. 131.

${ }^{60}$ BETHENCOURT, Francisco - O Imaginário da Magia ..., cit., p. 37-44.

${ }^{61}$ BRAGA, Isabel M. R. Mendes Drumond - Os Estrangeiros e a Inquisição Portuguesa (Séculos XVI-XVII). Lisboa: Hugin, 2002, p. 303.

${ }^{62}$ ANDRADE, Maria Filomena - Rainha Santa, Mãe Exemplar. Isabel de Aragão. Lisboa: Círculo de Leitores, 2012, p. 218. 
eram feitos por armas aos provocados por quedas, passando pelas úlceras), alguns males oculares, queimaduras e sarna ${ }^{63}$.

No século XVI, utilizava-se gema de ovo na preparação de um emplastro a colocar sobre os apostemas das vítimas de peste. Pelo menos, tal aconteceu num caso conhecido de Março de $1580^{64}$. Rafael Bluteau, no início do século XVIII, também referiu que com gemas de ovos se preparava uma manipulação relevante contra a peste, denominada electuarium ab ovo. Provavelmente, trata-se do mesmo emplastro já utilizado no século de Quinhentos. As virtudes terapêuticas do ovo eram igualmente úteis para outros problemas de saúde, segundo este autor. Assim, o ovo era diurético e, em aplicações tópicas, servia para acabar com febres intermitentes ${ }^{65}$.

O médico Francisco da Fonseca Henriques, na sua obra Anchora Medicinal, publicada em 1721, fez alguma apologia dos ovos. Entendendo que eram alimento e condimento de manjares, fez a destrinça entre o valor da gema "de boa substância" e a clara que "nutre muito". Considerou que deveriam ser consumidos frescos, em especial do mesmo dia em que tinham sido postos "que a estes chamam ovos de ouro, aos de dois dias, ovos de prata e aos do terceiro dia, ovos de ferro", e que era preferível escolher os que se apresentassem brancos e longos. Do ponto de vista terapêtico entendeu serem apropriados para pessoas de todas as idades, e, em especial, para convalescentes, debilitados e tísicos. Porém, gente biliosa deveria abster-se do consumo de ovos, enquanto os que tinham cálculos renais ou gota os poderiam ingerir segundo a sua opinião, que não era consensual na comunidade médica de então. Finalmente, o médico referiu-se ao que considerou serem as muitas virtudes medicinais dos ovos para diferentes males. As gemas serviam para eliminar dores de dentes e dores hemorroidais, para a supressão de manchas e sinais provocados por bexigas (varíola) e para a supuração de apostemas (tumores). As claras eram úteis quer ingeridas nos casos de pacientes que escarravam sangue quer como uso tópico em

${ }^{63}$ TAVARES, Maria José Pimenta Ferro - Hospitais, Doenças e Saúde Pública in Congresso Comemorativo do V Centenário da Fundação do Hospital Real do Espírito Santo de Évora. Actas. Évora: Hospital do Espírito Santo, 1996, p. 52-59.

${ }^{64}$ MIRA, M. Ferreira - História da Medicina Portuguesa. Lisboa: Empresa Nacional de Publicidade, 1947, p. 126.

${ }^{65}$ BLUTEAU, Rafael - Vocabulario Portuguez e Latino..., cit., vol. 6, p. 143. 
inflamações. As cascas dos ovos - depois de trituradas e transformadas em pó - poderiam ser utilizadas para quebrar e excluir as pedras dos rins, isto é os cálculos renais e, finalmente, a película branca que se encontra entre a casca e a clara era vista como portadora de virtudes diuréticas e cicatrizantes, nomeadamente quando colocada sobre feridas de caneladas ${ }^{66}$.

$\mathrm{Na}$ actualidade, a discussão médica é, naturalmente, outra. O problema da riqueza do ovo em gordura leva a que não seja aconselhado o consumo de mais do que um por dia para pessoas sem problemas de saúde mas a abstenção ou a redução significativa para os que padecem de colesterol elevado, se bem que esta tese tradicional não seja totalmente consensual. Por outro lado, atendendo à riqueza de cálcio que se encontra na casca de ovo - composta essencialmente por carbonato de cálcio - um dos caminhos propostos por nutricionistas é o seu aproveitamento na alimentação humana. Experiências efectuadas em Goiás levaram os investigadores a adicionar um grama de pó de casca de ovo a 100 gramas de cereal ou farinha, integrantes de 10 preparados de baixo custo e de consumo habitual na região: arroz cozido, arroz doce, beiju com margarina, biscoito de polvilho, biscoito frito doce, biscoito frito salgado, bolinho de chuva, bolo de fubá de milho, bolo simples e farofa de ovo e banana. As conclusões do estudo foram promissoras. A adição do pó de casca de ovo nas proporções referidas às formulações enunciadas permitiu contribuir de forma significativa para a ingestão de quantidades de cálcio suficientes para jovens e adultos, prevenindo a osteoporose, sem prejuízo do sabor dos pratos ${ }^{67}$.

Outras preocupações referem-se à qualidade sanitária dos ovos, o que se articula também com as questões de saúde. Na realidade, o que leva os

${ }^{66}$ HENRIQUES, Francisco da Fonseca - Anchora Medicinal..., cit., p. 176-180.

${ }^{67}$ NAVES, Maria Margareth Veloso, FERNANDES, Daniela Canuto, PRADO, Carla Marques Maia, TEIXEIRA, Luís Sávio Medeiros - Fortificação de Alimentos com Pó de Ovo como Fonte de Cálcio in Ciência, Tecnologia, Alimentos, vol. 27, n. ${ }^{\circ}$ 1, Campinas (2007) 99-103. Outros usos mais prosaicos para a casaca de ovo são, por exemplo, o seu aproveitamento enquanto fertilizante natural, como elemento que ajuda a controlar pragas de caracóis e lesmas, que facilita a limpeza de superfícies duras, e que, juntamente com a clara, pode ser utilizado como máscara de beleza. Cf. Ciência Relativa: 12 usos com a casca velha de ovo <http://cienciarelativa.blogspot.com/2011/06/12-usos-com-casca-velha-de-ovo. html > . Consultado a 19 de Julho de 2011. No passado, Bluteau referiu que os melhores relógios de areia, as ampulhetas, se faziam com cascas de ovo moídas e transformadas em pó. Cf. BLUTEAU, Rafael - Vocabulario Portuguez e Latino..., cit., vol. 6, p. 144. 
consumidores a adquirir os ovos num determinado espaço? A frescura, o tamanho, a higiene da casca, a cor da gema, o tamanho do ovo, a refrigeração ou o conhecimento da procedência do produto? Naturalmente que apenas pesquisas concretas podem dar respostas às interrogações. No caso de várias entrevistas levadas a cabo em diversas cidades do Estado de São Paulo, as respostas foram de molde a concluir que persistem muitas atitudes e ideias equivocadas por parte das consumidoras (só foram entrevistadas mulheres), sendo necessárias campanhas educativas para esclarecer as prioridades ${ }^{68}$. Não é difícil imaginar que as conclusões das autoras do estudo possam ser válidas quer para outros espaços brasileiros quer para Portugal.

No passado como no presente, os cosméticos foram seduzindo gerações ${ }^{69}$. A sua aplicação esteve sempre directamente relacionada com os estatutos sociais e culturais do utilizador. As concepções estéticas e os padrões de beleza variaram com as épocas e com os grupos humanos e, em alguns casos, o que para uns era sinónimo de beleza e distinção era, para outros, prova de selvajaria, mau gosto ou vulgaridade. Pensemos, por exemplo, que as índias pintadas, tatuadas e depiladas estavam longe de corresponder aos padrões estéticos dos europeus durante a Época Moderna, não obstante serem visíveis palavras de deslumbramento por parte de alguns que com as mesmas contactaram ${ }^{70}$.

${ }^{68}$ RODRIGUES, Kátia Regina Martini, SALAY, Elisabete - Atitudes de Granjeiros, Atacadistas, Varejistas e Consumidores em relação à Qualidade dos Ovos de Galinha in Natura, Revista de Nutrição, vol. 14, n. ${ }^{\circ}$ 3, Campinas (2001) 185-193. Sobre a relação alimentação de galinhas, cor da gema de ovo e colorantes da gema, cf. MARINO E BÍSCARO, Luciana, CANNIATI-BRAZACA, Solange Guidolin - Cor, Betacaroteno e Colesterol em Gema de Ovos obtidos de Poedeiras que receberam diferentes Dietas, Ciência e Agrotecnologia, vol. 30, Lavras (2006) 1-6.

${ }^{69}$ PITA, João Rui - Breve História dos Cosméticos in Munda, n. ${ }^{\circ} 32$, Coimbra (1996) 17-28; REBELO, Maria de Lourdes Godinho e PITA, João Rui - Cosméticos: sua evolução in Medicamento, História e Sociedade, n. ${ }^{\circ}$ 8, Coimbra (1988) 23-28; PEREIRA, Ana Leonor, PITA, João Rui - Liturgia Higienista no século XIX. Pistas para um Estudo, Revista de História das Ideias, vol. 15, Coimbra (1993) 437-559; Idem, La Publicité Pharmaceutique, Médicale et Cosmétique dans la Revue A Ilustração (Paris, 1884-1892), Revue d'Histoire de la Pharmacie, tomo 43, n. ${ }^{\circ}$ 309, Paris (1996) 159-168; Idem, Publicidade a Cosméticos (séculos XIX-XX), Munda, n. ${ }^{\circ}$ 35, Coimbra (1998) 29-40.

${ }^{70}$ PEREIRA, Ana Maria Fontes - As Muitas Faces de Eva: Imagens da Mulher Índia na Literatura sobre o Brasil (séculos XVI a XVII). Viseu: Dissertação de Mestrado em História da Época dos Descobrimentos Portugueses apresentada à Universidade Católica - Pólo de Viseu, 2002. 
No mundo ocidental, o uso de cosméticos, entendidos como produtos para limpar, corrigir, proteger, embelezar e retardar o envelhecimento cutâneo ou conservar e restabelecer a beleza dos dentes e dos cabelos ${ }^{71}$, difundiu-se durante o Renascimento, apesar de se terem verificado diversas resistências. O berço destas práticas, tal como o da estética em geral, foi a península itálica. Mas, um pouco por todo o lado, as críticas aos enfeites luxuosos, às modas e aos cosméticos marcou discursos de teólogos e moralistas, tendo também presença no teatro ${ }^{72}$ e na literatura dita popular.

Como a produção de artigos de beleza era artesanal e quase sempre caseira surgiram, um pouco por toda a Europa, diversos livros de receitas, alguns dos quais escritos por homens, de conteúdo eclético, dando conta de como preparar pratos de culinária, tinta de escrever, produtos diversos para eliminação de nódoas e ainda receitas de cosméticos diversos ${ }^{73}$. Portugal não constituiu excepção neste panorama, conhecendo textos castelhanos e franceses ${ }^{74}$ e produzindo os próprios. Tendo em conta um livro de receitas manuscrito da primeira metade do século XVIII, tanto quanto sabemos o

${ }^{71}$ Sobre o conceito e a finalidade dos cosméticos, cf. PITA, João Rui - Breve História dos Cosméticos..., cit., p. 17; BARATA, Eduardo A. F. - Cosméticos. Arte e Ciência. Lisboa, Porto, Coimbra, 2002.

${ }^{72}$ Em 1659, Molière escreveu uma peça intitulada As Preciosas Ridiculas. Na cena III o diálogo estabelecido entre Marieta e Gorgibus é revelador:

"Marieta - O que desejais Senhor?

Gorgibus - Onde estão as vossas amas?

Marieta - No seu gabinete.

Gorgibus - O que fazem?

Marieta - Pomada para os lábios.

Gorgibus - Muito pomadeiam elas... Dizei-lhe que desçam. Parece-me que, com as suas pomadas, essas inúteis querem arruinar-me. Por todo o lado só vejo claras de ovo, leite virginal e outras mil futilidades que desconheço. Desde que estamos aqui já gastaram, pelo menos, o toucinho de uma dúzia de porcos, e quatro criados viveriam diariamente com as patas de carneiro que elas usam".

${ }^{73}$ GRIECO, Sara F. Matthews - O Corpo, Aparência e Sexualidade in História das Mulheres no Ocidente, direcção de George Duby e Michelle Perrot, vol. 3 (Do Renascimento à Idade Moderna), coordenação de Arlette Farge e Natalie Zemon Davis, tradução revista por Maria Helena da Cruz Coelho e Leontina Ventura. Porto: Afrontamento, 1994, p. 86; VIGARELLO, George - Histoire de la Beauté. Le Corps et l'Art d'Embellir de la Renaissance à nos Jours. Paris: Seuil, 2004, p. 46. Para o caso dos livros ingleses, cf. LEHMANN, GillyThe British Housewife. Cookery Books, Cooking and Society in Eighteenth-Century Britain. Blackawaton: Prospect Books, 2003, p. 21, 30, 87, 92, 96, 163, passim.

${ }^{74}$ BUESCU, Ana Isabel - Imagens do Príncipe. Discurso Normativo e Representações (1525-49). Lisboa: Cosmos, 1996, p. 232. 
primeiro a apresentar receitas de cosméticos, analisemos o seu conteúdo. No que se refere às receitas de produtos de higiene e beleza, sabemos que as mesmas ocupam $5 \%$ do total da obra ${ }^{75}$. Nelas contam-se perfumes (líquidos e

Quadro 1 - Ovos e Receituário de Beleza

Receita de como se faz hum Vinho Excellente para o Rosto para todos os Dias

Tomarão huas uvas gallegas maduras e espreme las hão muito bem em hua vazilha vidrada e despoes lança se este sumo em hum frasco que fique bem cheio e deitarão la dentro hum ovo fresco do mesmo dia com clara e gema e deicharão o frasco destapado para que lance fora o que ferver e tanto que não escumar nada e estiver muito bem sentado no fundo do mesmo frasco o pe se deitara com vagar em outra vazilha o vinho de sorte que fique mui claro e se limpara o frasco da borra e despoes de limpo se lhe tornara a lançar o vinho que ya estara muito puro e clareficado e para que se possa concervar hum anno sem se azedar lhe deitarão hum torrão de asucar cande muito bem mohido e hum vintem de solimão e trinta reis de alcanfor do mesmo modo se tape o frasco muito bem e se ponha ao sereno e ao ar nove dias de sorte que lhe não de sol e despoes disto uzarão delle mas advertindo que se ha de tirar para hua vazilha hua pouca parte do tal vinho por que the não faz bem bolirse sempre em todo e esta quantidade de tempero he para frasco de duas canadas.

\section{Remedio para fazer Cabello donde falta}

Tomem em unto e almastica de cada hum hua onça e meia e bollo armenico e cascas de roman bical e não havendo sejão de doces e azedas partes iguais e semente de linojo tudo queimado e feito em po e tanto alquene como o de maio e tudo destemperado e batido com vinagre e claras de ovos com o que untarão a parte pera alguas vezes.

\section{Para se fazerem dos Cabellos Brancos Negros}

Pizarão as cascas das nozes verdes e as hestillarão a fogo brando e o licor que deitarem guardareis e com o pente uzaras delle guardando o rosto e as maos tãobem lavando a parte com ovos de corvas batidos aproveita o mesmo effeito faz a cor não estillada e com a agoa que deitem molhando nelle o pente se pintiarão.

${ }^{75}$ BRAGA, Isabel M. R. Mendes Drumond - O Livro de Cozinha de Francisco Borges Henriques in Do Primeiro Almoço à Ceia. Estudos de História da Alimentação. Sintra: Colares, 2004, p. 61-99. 
em pastilhas), pomadas para a cara e para os cabelos e ainda preparados para fazer crescer, escurecer e alourar o cabelo, a par de mistelas para eliminar verrugas e limpar os dentes. Em diversas destas receitas, nomeadamente um denominado vinho para o rosto, e dois preparados para cuidar dos cabelos, os ovos inteiros ou só a clara, apareceram como elementos que integravam esses cosméticos. Num caso, o do manipulado para escurecer o cabelo, especifica-se que deveriam ser de corvo fêmea, provavelmente porque os corvos são $\operatorname{pretos}^{76}$.

\section{O ovo na culinária do passado}

"Hum bom cozinheiro sabe fazer ovos de cento e cinquenta castas"77, eis o desafio ou a provocação de Rafael Bluteau, lançada após ter enunciado alguns títulos de receitas em que o ingrediente rei era o ovo: ovos escalfados, fritos, ou, em preparações mais sofisticadas, em aletria, em fatias, de talhadas, de trouxas, ovos reais "de muitas castas", sem esquecer pastelinhos de ovos-moles e ovos recheados com carneiro ou com peixe.

Na verdade, o consumo de determinados pratos, mormente doces, esteve quase sempre ligado à ideia de festa. Por exemplo, quando das do Corpo de Deus realizadas no Porto, entre as refeições servidas pelo concelho, os ovos ocupavam o seu lugar entre os produtos utilizados, de entre outros, na feitura de desfeitos ${ }^{78}$. Em 1475, entraram 10 dúzias de ovos e em 1494, 13 dúzias, embora neste caso alguns ovos possam ter sido utilizados na confecção de bolos ${ }^{79}$. Desfeitos eram também consumidos, no século XVI, pelas freiras do Convento de Santa Clara, de Santarém, em especial

${ }^{76}$ Fonte: Lisboa, Biblioteca Nacional de Portugal (B.N.P.), Cod. 7376 [Receitas de milhores doces e de alguns guizados particullares e remedios de conhecida experiencia que fes Francisco Borges Henriques para o uzo da sua caza. No anno de 1715. Tem seo alfabeto no fim. 1715-1729], fols 102, 131-134, publicado em BRAGA, Isabel M. R. Mendes Drumond - Beleza e Sedução: à volta dos Cosméticos in Vivências no Feminino. Poder, Violência e Marginalidade nos séculos XV a XIX. Lisboa: Tribuna da História, 2007, p. 174-175, 177.

${ }_{77}$ BLUTEAU, Rafael - Vocabulario Portuguez e Latino..., cit., vol. 6, p. 144.

${ }^{78}$ Prato confeccionado com carne picada, ovos, pão ralado e especiarias.

${ }^{79}$ GONÇALVES, Iria - As Festas do 'Corpus Christi' do Porto na segunda metade do século XV. A participação do concelho in Um Olhar sobre a Cidade Medieval. Cascais: Patrimonia, 1996, p. 1069-1070. 
durante o Natal e a Páscoa ${ }^{80}$, momentos importantes do calendário litúrgico associados a determinados pratos, o que permite associar os alimentos não apenas às questões naturais como também, e neste caso, sobretudo, às questões culturais ${ }^{81}$. Mesmo nos mosteiros masculinos, a presença da doçaria era significativa, em especial nas épocas festivas. Por exemplo, em São Martinho, de Tibães, a festa de São Bento era ocasião para a aquisição de muitos doces nos quais os ovos assumiam um lugar de destaque: biscoitos, manjar real, melindres, ovos de ferraduras, ovos queimados, ovos reais, pastéis, pastéis dos remédios, tigelinhas de ovos-moles e viúvas, de entre outros ${ }^{82}$.

Na doçaria conventual, ovos, açúcar e, muitas vezes, amêndoas foram ingredientes omnipresentes. As comunidades femininas dedicaram-se frequentemente à doçaria para consumo próprio, oferta e comercialização, neste caso obtendo uma fonte de receita para as casas religiosas. Porém, nem sempre a actividade esteve isenta de problemas, nomeadamente em algumas épocas do calendário litúrgico quando as freiras se ocupavam mais dos afazeres culinários do que das práticas espirituais, merecendo críticas por parte dos visitadores ${ }^{83}$. De notar que as designações de algumas receitas conventuais, nomeadamente as que usavam e abusavam dos ovos, remetem frequentemente para o universo quotidiano das monjas: barriguinhas de freiras, bolo do paraíso, broas de milho de Santa Clara, fatias de Santa Clara, manjar celeste e queijinhos do céu são exemplos, para ficarmos pelas receitas compiladas em 1729 pela irmã Leocádia do Monte do Carmo, do convento de Santa Clara, de Évora ${ }^{84}$. Nunca é de mais salientar que algumas receitas

${ }^{80}$ BEIRANTE, Ângela - Santarém Quinhentista. Lisboa, [s.n.], 1981, p. 247-252.

${ }^{81}$ Sobre estas questões, cf. MONTANARI, Massimo - Il Cibo como Cultura. Roma: Bari, Laterza, 2007, p. 105-108.

${ }^{82}$ RAMOS, Anabela, SOARES, Deolinda e OLIVEIRA, Paulo - A Festa de São Bento: uma Viagem pela Gastronomia Beneditina, Mínia, 2. ${ }^{a}$ série, n. ${ }^{\circ}$ 11-12, Braga (2004-2005) 71-112.

${ }^{83}$ Cf. BRAGA, Isabel M. R. Mendes Drumond - Vaidades nos Conventos Femininos ou das Dificuldades em deixar a Vida Mundana (séculos XVII-XVIII), Revista de História da Sociedade e da Cultura, vol. 10, tomo 1, Coimbra (2010) 305-322. Disponível no endereço $<$ http://www.uc.pt/chsc/rhsc/rhsc_10>.

${ }^{84}$ Cf. MONTE DO CARMO, Soror Maria Leocádia do - Livro das Receitas de Doces e Cozinhados vários d'este Convento de Santa Clara d'Évora. 1729, apresentação e notas de Manuel Silva Lopes. Lisboa: Barca Nova, 1988; ALGRANTI, Leila Mezan - Doces de Ovos, Doces de Freiras: a Doçaria dos Conventos portugueses no Livro de Receitas da Irmã 
de doces conventuais portugueses chegaram ao Brasil, marcando a doçaria de determinadas regiões, de que é um bom exemplo, Pelotas, famosa pelos pastéis de Santa Clara, papos de anjos e tantos outros doces de origem conventual portuguesa ${ }^{85}$.

Passemos um olhar atento pelos livros de culinária da Época Moderna que chegaram ao presente. De qualquer modo, quer os manuscritos quer os impressos não são muito abundantes ${ }^{86}$. Apesar da pobreza numérica dos textos, comparativamente ao que se conhece para outros Reinos da Europa ${ }^{87}$, recentemente têm sido publicados alguns conjuntos de receitas de casas particulares e de instituições religiosas que enriqueceram o conhecimento do receituário nacional dos séculos XVII a $\mathrm{XX}^{88}$.

Maria Leocádia do Monte do Carmo (1729), Cadernos Pagu, n. ${ }^{\circ}$ 17-18, Campinas (2001-2002) 397-408.

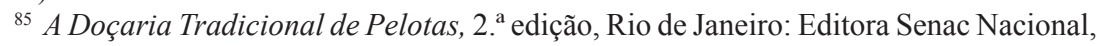
2004.

${ }^{86}$ Veja-se o elenco das existências da Biblioteca Nacional de Lisboa, a par de um ou outro

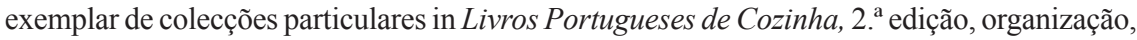
levantamento bibliográfico e iconográfico de Manuela Rêgo, Lisboa: Biblioteca Nacional, 1998.

${ }^{87}$ MENNELL, Stephen - All Manners of Food. Eating and Taste in England and France from the Middle Ages to the Present, 2. ${ }^{a}$ edição. Urbana and Chicago: University of Illinois Press, 1996, p. 166-199; HYMAN, Philip, HYMAN, Mary - Imprimer la Cuisine: Les Livres de Cuisine en France entre le $\mathrm{XV}^{\mathrm{e}}$ et le $\mathrm{XVI}^{\mathrm{e}}$ siècles in Histoire de l'Alimentation, dir. de Jean Paul Flandrin et Massimo Montanari. Paris: Fayard, 1996, p. 643-655; Idem, Livres et Cuisine au XIX ${ }^{\mathrm{e}}$ siècle in $A$ Table au XIXe siècle. Paris: Musée d'Orsay, Flammarion, 2001, p. 80-89; LAURIOUX, Bruno - Le Règne de Taillevent. Livres et Pratiques Culinaires à la fin du Moyen Age. Paris: Publications de la Sorbonne, 1997; EHLERT, Trude - Les Manuscrits Culinaires Médiévaux témoignent-ils d'un Modèle Alimentaire Allemand? in Histoire et Identités Alimentaires en Europe, dir. de Martin Bruegel et Bruno Laurioux. [s.1.]: Hachette, 2002, p. 121-136.

88 TAVARES, Paulino Mota-Mesa, Doces e Amores no Século XVII Português, prefácio de Maria José Azevedo Santos. Sintra: Colares, 1999; Doces e Manjares do Século XIX. O Livro do Padre Brito, prefácio de Maria José Azevedo Santos, leitura e notas de Paulino Mota Tavares. Coimbra: Fora de Texto, 1995; O Livro de Receitas da Última Freira de Odivelas, introdução, actualização do texto e notas de Maria Isabel de Vasconcelos Cabral. Lisboa: Verbo, 1999; TAVARES, Paulino Mota e CAVALHEIROS, Maria Leonor - Quinta das Lágrimas. Cenário dos Amores de Pedro e Inês. História, Requintes e Sabores. Sintra: Colares, 2002. Vejam-se ainda algumas receitas e um estudo sobre um interessante livro de cozinha de Francisco Borges Henriques, escrito na primeira metade do século XVIII, in BRAGA, Isabel M. R. Mendes Drumond - O Livro de Cozinha de Francisco Borges Henriques in Do Primeiro Almoço à Ceia. Estudos de História da Alimentação. Sintra: Colares, 2004, p. 61-99. 
Na impossibilidade de, no âmbito de um artigo, se estudarem todas as receitas de doces e de salgados em cuja composição entram ovos, optámos pela análise de uma receita concreta, a de ovos-moles, actualmente um produto tradicional de origem e proveniência certificadas, o primeiro doce português a receber tal distinção e com confraria desde 26 de Março de 2009. Se os ovos-moles de Aveiro, tal como hoje se conhecem, não constam das obras de cozinha da Época Moderna ${ }^{89}$, as receitas de ovos-moles estão presentes nas obras de Domingos Rodrigues (1680), de Lucas Rigaud (1780), na anónima Arte Nova e Curiosa para Conserveiros, Confeiteiros e Copeiros (1788) e no manuscrito de Francisco Borges Henriques (1715-1729). Desde logo, impõe-se verificar que receitas com a mesma designação não apresentam necessariamente os mesmos ingredientes nem idênticas maneiras de preparar o doce. Aliás, num caso, a receita de ovos-moles é um prato salgado.

Nas nove receitas dos séculos XVII e XVIII, com a designação de ovos-moles, pode verificar-se que, tal como acontecia em relação a outros preparados, não se verifica separação entre ingredientes e modo de confecção, não se indica o tempo de cozedura, nem se informa acerca do número de doces que cada receita permitia obter.

${ }^{89}$ Note-se que o mais antigo livro de receitas português contém um capítulo sobre manjares de ovos mas nele não consta a receita de ovos-moles. Cf. Livro de Cozinha da Infanta D. Maria, prólogo, leitura, notas aos textos, glossário e índices de Giacinto Manuppella, Lisboa, Imprensa Nacional-Casa da Moeda, 1987. Sobre esta obra, foram produzidos trabalhos visando o estudo das questões alimentares e da análise codicológica do manuscrito. Cf. MARQUES, A. H. de Oliveira - A Sociedade Medieval Portuguesa. Aspectos de Vida Quotidiana, 4. ${ }^{\text {a }}$ edição. Lisboa: Sá da Costa, 1981, p. 7-22; ARNAUT, Salvador Dias A Arte de Comer em Portugal na Idade Média. Lisboa: Imprensa Nacional-Casa da Moeda, 1986; O Mais Antigo Livro de Cozinha Português. Receitas e Sabores in A Alimentação em Portugal na Idade Média, Fontes. Cultura. Sociedade. Coimbra: [s.n.], 1997, p. 35-66; TELLES, Célia Marques - Características Grafemático-Fonéticas de um Manuscrito em Letra Gótica Cursiva in IV Encontro Internacional de Estudos Medievais. Anais, organização de Ângela Vaz Leão e Vanda de Oliveira Bittencourt. Belo Horizonte: Pontifícia Universidade Católica de Minas Gerais, 2003, p. 731-738. 
Quadro 2 - Receitas de Ovos-Moles (séculos XVII e XVIII) em Livros de Leigos

\begin{tabular}{|c|c|c|c|}
\hline $\begin{array}{l}\text { Domingos Rodrigues, } \\
\text { Arte de Cozinha } \\
(1680)^{90}\end{array}$ & $\begin{array}{c}\text { Receituário Manuscrito } \\
\text { de Francisco Borges } \\
\text { Henriques } \\
(1715-1729)^{91}\end{array}$ & $\begin{array}{c}\text { Lucas Rigaud, } \\
\text { Cozinheiro Moderno } \\
(1780)^{92}\end{array}$ & $\begin{array}{c}\text { Arte Nova e Curiosa } \\
\text { para Conserveiros, } \\
\text { Confeiteiros... }(1788)^{93}\end{array}$ \\
\hline Ovos-Moles & $\begin{array}{l}\text { Ovos molles brancos } \\
\text { para comer logo }\end{array}$ & $\begin{array}{l}\text { Ovos-Moles de vários } \\
\text { modos ou Escalfados }\end{array}$ & $\begin{array}{c}\text { Receita de } \\
\text { Ovos-Moles }\end{array}$ \\
\hline $\begin{array}{l}\text { Deite-se (sic) em um } \\
\text { arrátel de açúcar em } \\
\text { ponto alto, quinze } \\
\text { gemas de ovos, mexam- } \\
\text { se muito bem enquanto } \\
\text { se forem cozendo: } \\
\text { depois de cozidos } \\
\text { deitem-se no prato, e } \\
\text { mandem-se à mesa com } \\
\text { canela por cima. }\end{array}$ & $\begin{array}{l}\text { A hum arratel de asucar } \\
\text { deitarão dezoito ovos } \\
\text { e so lhes deitarão três } \\
\text { com claras, os quais se } \\
\text { baterão como para ovos } \\
\text { molles e o asucar se } \\
\text { pora em ponto de ovos } \\
\text { molles. Tirar ce hão do } \\
\text { lume despois de estar } \\
\text { em tempara e despois } \\
\text { de abater a escuma se } \\
\text { lhe deitarão os ovos e se } \\
\text { mecherão muito bem e } \\
\text { se baterão com hum pao } \\
\text { de fazer fatias de pão } \\
\text { de lo the ficarem muito } \\
\text { brancos e ao despois } \\
\text { se levarão ao lume não } \\
\text { mais que a quentar e } \\
\text { se deitarão em tigela } \\
\text { ou pratos com canella } \\
\text { por sima. Estes ovos } \\
\text { em prato com obreias d } \\
\text { ovo feitas em canudo e } \\
\text { embrulhados no mesmo } \\
\text { fundo com hum fuzo he } \\
\text { dos pratos gavados (?). }\end{array}$ & $\begin{array}{l}\text { Ponham-se ao lume } \\
\text { numa caçarola meia } \\
\text { de água com sal e um } \\
\text { pouco de vinagre; em } \\
\text { fervendo cozam nela os } \\
\text { ovos que sejam frescos } \\
\text { e quebrando-os, fiquem } \\
\text { uns separados de outros; } \\
\text { tirem-se fora antes que } \\
\text { endureçam, passem-se } \\
\text { para outra água que es- } \\
\text { teja morna; aparem-se } \\
\text { e sirvam-se com vários } \\
\text { molhos, como molho de } \\
\text { substância, de essência, } \\
\text { de presunto, sóssa [isto } \\
\text { é, sauce] Robert, sóssa } \\
\text { de enxovas, e alcapar- } \\
\text { ras, molho branco, } \\
\text { molho verde, com ragus } \\
\text { de legumes, como são } \\
\text { espargos, alfaces, chi- } \\
\text { córias, aipo, espinafres } \\
\text { e azedas, ragu de trufas, } \\
\text { de molejas, de cogu- } \\
\text { melos ou qualquer outro } \\
\text { que bem parecer. }\end{array}$ & $\begin{array}{l}\text { A cada dois arráteis de } \\
\text { açúcar duas dúzias e } \\
\text { meia de ovos e fazem- } \\
\text {-se nesta forma: depois } \\
\text { de clarificado o açúcar, } \\
\text { deitarão arrátel e meio } \\
\text { em um tacho e depois } \\
\text { de estar alguma coisa } \\
\text { grosso passarão as fa- } \\
\text { rias e as porão logo } \\
\text { por ordem no prato em } \\
\text { que houverem de deitar } \\
\text { os ovos e deitarão um } \\
\text { pequeno de açúcar por } \\
\text { cima das fatias, para que } \\
\text { fiquem bem brandas, } \\
\text { e do meio arrátel que } \\
\text { tinham apartado deita- } \\
\text { rão no tacho a parte } \\
\text { maior e deixarão en- } \\
\text { grossar, até ponto de } \\
\text { espadana que caia da } \\
\text { colher, e terão os ovos } \\
\text { batidos, só as gemas, e } \\
\text { as botarão neste açúcar } \\
\text { com fogo brando e me- } \\
\text { xendo sempre com a }\end{array}$ \\
\hline
\end{tabular}

${ }^{90}$ RODRIGUES, Domingos - Arte de Cozinha, leitura, apresentação, notas e glossário por Maria da Graça Pericão e Maria Isabel Faria. Lisboa: Imprensa Nacional-Casa da Moeda, 1987, p. 158.

${ }^{91}$ Lisboa, B.N.P., Cod. 7376 [Receitas de milhores doces e de alguns guizados particullares e remedios de conhecida experiencia que fes Francisco Borges Henriques para o uzo da sua caza. No anno de 1715. Tem seo alfabeto no fim. 1715-1729], fols 25, 36.

${ }^{92}$ RIGAUD, Lucas - Cozinheiro Moderno, ou Nova Arte de Cozinha, prefácio de Alfredo Saramago. Sintra: Colares, 1999, p. 210-211.

${ }_{93}$ Arte Nova e Curiosa para Conserveiros, e Copeiros e mais Pessoas que se ocupam em fazer Doces e Conservas com Frutas de várias qualidades e outras muitas Receitas particulares da mesma Arte, estudo e actualização do texto de Isabel M. R. Mendes Drumond Braga. Sintra: Colares, 2004, p. 48-49. 


\begin{tabular}{|c|c|c|c|}
\hline $\begin{array}{l}\text { Domingos Rodrigues, } \\
\text { Arte de Cozinha } \\
(1680)^{90}\end{array}$ & $\begin{array}{c}\text { Receituário Manuscrito } \\
\text { de Francisco Borges } \\
\text { Henriques } \\
(1715-1729)^{91}\end{array}$ & $\begin{array}{c}\text { Lucas Rigaud, } \\
\text { Cozinheiro Moderno } \\
(1780)^{92}\end{array}$ & $\begin{array}{c}\text { Arte Nova e Curiosa } \\
\text { para Conserveiros, } \\
\text { Confeiteiros... (1788) }\end{array}$ \\
\hline & & & $\begin{array}{l}\text { colher e sempre para } \\
\text { diante e como limpam } \\
\text { o tacho estão feitos. } \\
\text { Tirem-nos do fogo e } \\
\text { os ponham sobre as } \\
\text { fatias que acima digo e } \\
\text { a menor parte do açúcar } \\
\text { que tínhamos deixado } \\
\text { botarão no tacho e } \\
\text { engrossarão e botarão } \\
\text { sobre o prato dos ovos } \\
\text { e se quiserem os podem } \\
\text { pulverizar com açúcar } \\
\text { em pó e canela. }\end{array}$ \\
\hline & $\begin{array}{l}\text { Ovos molles de que } \\
\text { uzamos } \\
\text { A cada arratel de asucar } \\
\text { se deitarão dezasseis } \\
\text { ovos em ponto de } \\
\text { cabelinho quebram ce } \\
\text { os ovos e hum com } \\
\text { clara e batidos todos } \\
\text { muito bem batidos se } \\
\text { deicha esfriar o asucar } \\
\text { e despoes de estar em } \\
\text { ponto se deitam os } \\
\text { ovos todos de pancada } \\
\text { dentro e se mechem } \\
\text { muito bem e tornão a po } \\
\text { llos ao lume mexendo } \\
\text { ce sempre muito the } \\
\text { estarem groços e como } \\
\text { estiverem como caldo } \\
\text { de farinha groco os } \\
\text { deitarão aonde quiserem } \\
\text { não enchendo muito } \\
\text { as vasilhas porque } \\
\text { levantão no forno e o } \\
\text { milhor he cora los em } \\
\text { caza com a tampa de } \\
\text { cobre porque basta lhe } \\
\text { faça hua crues. }\end{array}$ & & $\begin{array}{l}\text { Receita de Ovos-Moles } \\
\text { que possam ir à Índia } \\
\text { Arrátel e meio de açú- } \\
\text { car, duas dúzias de ovos, } \\
\text { só gemas. Depois de o } \\
\text { açúcar estar clarificado } \\
\text { o porão em ponto de } \\
\text { espadana, estando assim } \\
\text { tirarão o tacho do lume } \\
\text { e o ponham no chão o } \\
\text { espaço de meio quarto } \\
\text { de hora e ali lhe deitarão } \\
\text { as gemas batidas de } \\
\text { golpe todas juntas e as } \\
\text { mexerão muito bem, } \\
\text { até que se liguem com } \\
\text { o açúcar e depois disso } \\
\text { tornarão o tacho ao lu- } \\
\text { me e cozerão os ovos } \\
\text { mexendo sempre no } \\
\text { meio do tacho e o lume } \\
\text { brando e muito cuidado } \\
\text { que se não queime e } \\
\text { irão cozendo os ovos } \\
\text { até que tomem a colher } \\
\text { e a sacudam no tacho } \\
\text { e os que caírem se não } \\
\text { misturem com os outros } \\
\text { se não hão-de ficar } \\
\text { de riba e então estão }\end{array}$ \\
\hline
\end{tabular}




\begin{tabular}{|c|c|c|c|}
\hline $\begin{array}{l}\text { Domingos Rodrigues, } \\
\text { Arte de Cozinha } \\
(1680)^{90}\end{array}$ & $\begin{array}{c}\text { Receituário Manuscrito } \\
\text { de Francisco Borges } \\
\text { Henriques } \\
(1715-1729)^{91}\end{array}$ & $\begin{array}{l}\text { Lucas Rigaud, } \\
\text { Cozinheiro Moderno } \\
\qquad(1780)^{92}\end{array}$ & $\begin{array}{c}\text { Arte Nova e Curiosa } \\
\text { para Conserveiros, } \\
\text { Confeiteiros... (1788) }{ }^{93}\end{array}$ \\
\hline & & & $\begin{array}{l}\text { cozidos e os tirem e } \\
\text { deitem em panelas. } \\
\text { Depois disto tomarão } \\
\text { um pouco de açúcar no } \\
\text { tacho limpo e o porão } \\
\text { em ponto de marmelo e } \\
\text { deitarão dele nas bocas } \\
\text { das panelas até que } \\
\text { cubram os ovos, depois } \\
\text { de frio fica como cara- } \\
\text { melo. E assim vão à } \\
\text { Índia, porque quando } \\
\text { se partem estão os ovos } \\
\text { por baixo muito brandos } \\
\text { e não se corrompem. } \\
\text { E não se faça de cada } \\
\text { vez mais que quatro dú- } \\
\text { zias, que ficam melho- } \\
\text { res poucos a poucos. }\end{array}$ \\
\hline & $\begin{array}{l}\text { Outros [ouos molles] } \\
\text { mais excelentes do } \\
\text { Brazil } \\
\text { Tomarão as gemas de } \\
\text { ouos pardos e as hirão } \\
\text { deitando em hum ren- } \\
\text { go e descoarão por } \\
\text { elle para hua vazilha e } \\
\text { terão o asucar limpo em } \\
\text { ponto de ficar bem e frio } \\
\text { que esteja medirão hua } \\
\text { tijella de calda e outra } \\
\text { de ouos e hirão ao tacho } \\
\text { aonde mecherão hua e } \\
\text { outra couza the cozer e } \\
\text { se lhe quizerem deitar } \\
\text { amendoa lha deitarão } \\
\text { a meio cozer que fique } \\
\text { groço o que baste. }\end{array}$ & & $\begin{array}{l}\text { Receita de Ovos-Moles } \\
\text { que se fazem } \\
\text { na Castanheira } \\
\text { Tomarão um arrátel de } \\
\text { açúcar bom e depois de } \\
\text { clarificado o porão em } \\
\text { ponto de espadana, que } \\
\text { não seja muito grosso, } \\
\text { e como estiver assim } \\
\text { o tirarão do lume e lhe } \\
\text { deitarão duas dúzias de } \\
\text { gemas de ovos muito } \\
\text { bem batidos e como as } \\
\text { mexerem bem as porão } \\
\text { no lume e os cozerão } \\
\text { até que limpe bem } \\
\text { no tacho, que pareça } \\
\text { ficam bem cozidos e os } \\
\text { deitarão em uma panela } \\
\text { vidrada e assim irão } \\
\text { cozendo arrátel e arrátel } \\
\text { até encher a panela de } \\
\text { açúcar, e depois lhe } \\
\text { porão por cima uma } \\
\text { capa de açúcar, posto }\end{array}$ \\
\hline
\end{tabular}




\begin{tabular}{|c|c|c|c|}
\hline \multirow[t]{3}{*}{$\begin{array}{l}\text { Domingos Rodrigues, } \\
\text { Arte de Cozinha } \\
(1680)^{90}\end{array}$} & \begin{tabular}{|c|} 
Receituário Manuscrito \\
de Francisco Borges \\
Henriques \\
$(1715-1729)^{91}$
\end{tabular} & $\begin{array}{c}\text { Lucas Rigaud, } \\
\text { Cozinheiro Moderno } \\
\qquad(1780)^{92}\end{array}$ & $\begin{array}{c}\text { Arte Nova e Curiosa } \\
\text { para Conserveiros, } \\
\text { Confeiteiros... (1788) }\end{array}$ \\
\hline & & & $\begin{array}{l}\text { em ponto muito alto de } \\
\text { cobrir. E levará cada } \\
\text { arrátel de açúcar dúzia e } \\
\text { meia de gemas de ovos } \\
\text { e para se cozerem se } \\
\text { deve limpar muito bem } \\
\text { o tacho. }\end{array}$ \\
\hline & \begin{tabular}{|l} 
Outros ovos molles \\
brancos \\
A hum arratel de asucar \\
posto em ponto de \\
quebrar deitarão dezoito \\
ovos e so tres com claras \\
e estes ovos os baterão \\
muito e emquanto os \\
não deitarem no asucar \\
os estarão sempre \\
batendo e inda quando \\
os forem deitando \\
nelle e estara ao mismo \\
tempo outra pessoa \\
mechendo os com hua \\
colher no asucar e \\
assim os porão em lume \\
brando e mechendo se \\
sempre the que queiram \\
levantar fervura que \\
emtão se tirem e lancem \\
em prato ou palangana.
\end{tabular} & & \\
\hline
\end{tabular}

Estamos perante um conjunto diversificado de receitas, todas com a designação de ovos-moles, as quais apresentaram aspectos comuns, nomeadamente o uso de gemas de ovos e de açúcar, embora em dois casos também se usem algumas claras. A proporção destes dois ingredientes variou (isto é, a cada arrátel de açúcar, ou seja a cada 0,459 quilos foram utilizadas $12,15,16,18$ ou 24 gemas), a utilização de diversos pontos de açúcar também se fez notar em algumas das preparações, nomeadamente alto, de cabelinho, de espadana, de marmelo e de quebrar, ao mesmo tempo que a canela foi sugerida como aromatizante em mais do que uma receita. Em dois casos, temos a indicação de duas fórmulas regionais, nestes casos 
da Castanheira e do Brasil, o que, no caso da colónia, parece corresponder a uma readaptação da receita original, apesar de conter um elemento bem português, amêndoa, inexistente então naquele território. Por outro lado, receitas para suportarem viagens marítimas longas também foram referidas. O ponto de açúcar permitia a conservação mais duradoura. Note-se que todos estes preparados apareceram em receituários da autoria de leigos, embora em diversos casos, os autores tivessem conhecimento de receitas conventuais, facto que não escamoteavam, mas nunca o fizerem relativamente aos ovos-moles. De salientar que a hóstia ou obreia para envolver os referidos ovos-moles foi indicada, pela primeira vez, num receituário manuscrito da primeira metade do século XVIII.

Olhemos agora para o receituário conventual. Apenas encontrámos duas receitas de ovos-moles ${ }^{94}$. A primeira, do século XVIII, concretamente de 1743, encontra-se num livro de um convento masculino, isto é, o Caderno de Refeitório ${ }^{95}$, a segunda consta do Livro de Receitas da última Freira de Odivelas, uma compilação que reúne receitas dos séculos XV a XIX, pelo que torna impossível perceber a partir de que momento era preparada no mosteiro, sendo plausível apontar os séculos XVII ou XVIII ${ }^{96}$. Em ambos os casos as receitas em nada se distinguem das congéneres dos receituários leigos, como se pode ver pelo quadro. Em suma, para os séculos XVII e XVIII, encontramos 11 receitas de ovos-moles: duas de receituários religiosos e nove de receituários leigos, tornando claro que o doce estava divulgado dentro e fora dos espaços conventuais e monásticos.

${ }^{94}$ Este número poderá aumentar, tendo em conta a recente disponibilização de dois manuscritos conventuais que temos em estudo.

${ }^{95}$ Caderno do Refeitório. Comezainas, Mezinhas e Guloseimas, apresentação e notas de Luís Filipe Coelho, 2. ${ }^{a}$ edição. Lisboa: Barca Nova, [1989], p. 67.

${ }^{96}$ O Livro da Última Freira de Odivelas, introdução, actualização do texto e notas de Maria Isabel de Vasconcelos Cabral. Lisboa: Verbo, 1999, p. 56. 
Quadro 3 - Receitas de Ovos-Moles (séculos XVII e XVIII) em Livros de Eclesiásticos

\begin{tabular}{|c|c|}
\hline Caderno do Refeitório & $\begin{array}{c}\text { O Livro de Receitas da } \\
\text { Última Freira de Odivelas }\end{array}$ \\
\hline Ovos-Moles & Ovos-Moles \\
\hline $\begin{array}{l}\text { Deitem-se em uma libra de açúcar em } \\
\text { ponto alto, quinze gemas de ovos, mexam- } \\
\text {-se muito bem enquanto forem cozendo, } \\
\text { para que se não peguem e no fim lhes } \\
\text { deitem água de flor e canela. }\end{array}$ & $\begin{array}{l}\text { Batem-se não muito } 15 \text { gemas e duas } \\
\text { claras. Poe-se uma medida de açúcar } \\
\text { em ponto que quebre, e no mesmo lume } \\
\text { que deve ser brando, se lançam os ovos, } \\
\text { mexendo-se muito depressa. Tiram-se, } \\
\text { voltam-se a por, mexendo sempre até } \\
\text { engrossarem suficientemente. Quando } \\
\text { ferver se lhe deita canela pisada e se forem } \\
\text { ao forno deve estar muito brando. }\end{array}$ \\
\hline
\end{tabular}

Se tivermos em conta o que actualmente se sabe acerca dos ovos-moles de Aveiro, nomeadamente a composição da receita (gemas, açúcar em ponto - para uns de cabelo, para outros de estrada e para outros ainda de pasta) com invólucro de obreia ou hóstia passado por leve calda de açúcar ou com recurso ao armazenamento em barricas de madeira decoradas com paisagens da Ria de Aveiro - uma ideia original de Edmundo Chaves, datada da primeira metade do século XX - podemos considerar que as receitas actuais têm origem incerta, resultam de eventual transmissão oral de antigas freiras de algum dos conventos femininos de Aveiro ${ }^{97}$ e têm antecedentes desde 1680, na obra já referida de Domingos Rodrigues. O recurso ao fogão de lenha, ao tacho de cobre, ao alguidar de barro e aos ovos de criação particular foi tendo tendência a desaparecer quer pelas novas opções das baterias de cozinha quer pela legislação reguladora da comercialização dos produtos alimentares. Não obstante, a qualidade do produto, a tradição do saber fazer e a consequente obtenção da designação de produto tradicional de origem e proveniência certificadas valem aos ovos-moles de Aveiro um estatuto.

${ }^{97}$ Cf. a obra colectiva e com contributos muito diversificados intitulada Ovos-Moles de Aveiro, [Aveiro], Confraria de São Gonçalo, s.d. Agradecemos à Senhora Dr. ${ }^{a}$ Carla Serôdio o envio deste texto em formato digital. 


\section{Ovos, ovos, ovos e mais ovos}

Seja qual for a perspectiva de abordagem, e neste texto, estamos longe de as ter esgotado, apesar de termos percorrido, a arte, a cultura popular, a economia, a medicina, a dietética e a gastronomia, cremos que merecem toda a atenção enquanto recurso alimentar fácil de obter, a preços competitivos, comparativamente a outros géneros, e de elevado valor nutricional. Por outro lado, os ovos permitem ser encarados do ponto de vista simbólico e reinventados à mesa de forma constante tanto nos pratos doces quanto nos salgados. O valor de algumas receitas, em termos de património imaterial, e a possibilidade que as mesmas têm de atrair o turismo gastronómico significa que vale a pena investir na qualidade e na divulgação do receituário regional de Norte a Sul do país. 